\title{
Energy balance closure and advective fluxes at ADVEX sites
}

\author{
Uta Moderow $^{1}$ (D) $\cdot$ Thomas Grünwald $^{1} \cdot$ Ronald Queck $^{1} \cdot$ Uwe Spank $^{1} \cdot$ Christian Bernhofer $^{1}$
}

Received: 7 January 2019 / Accepted: 25 September 2020 / Published online: 11 November 2020

(C) The Author(s) 2020

\begin{abstract}
When measuring the energy balance at the earth's surface using the Eddy covariance technique, the obtained budgets seldom produce a closed energy balance. The measurements often miss some of the energy fluxes. A possible reason is the neglect of non-turbulent surface fluxes of latent heat and sensible heat, i.e. advective fluxes of these quantities. We present estimates of advective latent and sensible heat fluxes for three different sites across Europe based on the ADVEX dataset. The obtained horizontal and vertical advective fluxes were site-specific and characterized by large scatter. In relative terms, the data indicated that the sensible heat budget was less affected by advection than the latent heat budget during nighttime; this is because vertical turbulent latent heat fluxes were very small or close to zero during the night. The results further showed that the additional energy gain by sensible heat advection might have triggered enhanced evaporation for two sites during nighttime. Accounting for advective fluxes improved the energy balance closure for one of the three ADVEX sites. However, the energy balance closure of the other two sites did not improve overall. A comparison with energy balance residuals (energy missed by the measurements without accounting for advection) indicated a large influence of systematic errors. An inspection of the energy balance for the sloped site of the ADVEX dataset underlined the necessity of slope-parallel measurement of radiation.
\end{abstract}

\section{Introduction}

The energy balance is fundamental in the interconnected earth-atmosphere system (Odum 1983; Oke 1987). Equation 1 denotes the energy balance at the earth's surface.

$R_{n}-G=H+\mathrm{LE}$,

where $R_{n}$ denotes net radiation, $G$ ground heat flux, $H$ sensible heat flux, and LE latent heat flux. The left hand side of Eq. 1 is termed available energy (AE). AE is partitioned between the sensible heat flux $(H)$ and the latent heat flux (LE), both of which redistribute the available energy back into the atmosphere. All terms in Eq. 1 are in $\mathrm{W} \mathrm{m}^{-2}$. The energy balance is a formulation of the first law of thermodynamics (energy conservation). Not all components of Eq. 1 can be directly measured at the earth's surface; therefore, we have to account for possible heat storage changes $(J)$ between the earth's surface and a chosen reference height above the earth's surface. Equation 1 becomes to:

Uta Moderow

uta.moderow@tu-dresden.de

1 Faculty of Environmental Sciences, Institute of Hydrology and Meteorology, Technische Universität Dresden, Dresden, Germany
$R_{n}-G-J=H+\mathrm{LE}$,

where the available energy now includes $J$ (storage changes) in $\mathrm{W} \mathrm{m}^{-2}$. It is not always possible to close the energy balance based on the measurements obtained (e.g. Tsvang et al. 1991; Kanemasu et al. 1992; Wilson et al. 2002; Foken 2008; Franssen et al. 2010; Stoy et al. 2013; Gerken et al. 2018; McGloin et al. 2018); that is, the sum of the measured fluxes of the left and right hand side of Eq. 1 and Eq. 2, respectively, is not equal. This is known as lack of energy balance closure, or energy balance closure gap. An energy balance closure gap between 10 and $30 \%$ is reported for most sites and often the sum of the latent and sensible heat flux is underestimated in relation to AE (Wilson et al. 2002; Foken 2008; Franssen et al. 2010; Stoy et al. 2013). However, there are also a few studies (Heusinkveld et al. 2004; Mauder et al. 2007a) which report an almost closed energy balance for measurements above rather homogeneous terrain.

Sensible and latent heat fluxes are usually measured by the Eddy covariance (EC) method. This method has been established as the method of choice for measuring fluxes of sensible and latent heat above different surfaces for more than two decades (Goulden et al. 1996; Aubinet et al. 1999; Baldocchi 2003; Aubinet et al. 2012a; Baldocchi 2014). However, the EC method detects turbulent exchanges between the earth's surface and the atmosphere. It therefore 
misses non-turbulent advective transports, which are relevant during conditions of low turbulence, typically at night (Aubinet et al. 2003, 2005; Marcolla et al. 2005; Aubinet 2008; Aubinet et al. 2012b). Therefore, neglecting advection can contribute to an unclosed energy balance. Other factors can also contribute to an unclosed energy balance. Wilson et al. (2002), Foken (2008), Foken et al. (2011), and Gao et al. (2017) address these further factors. Here, we focus on advection.

Numerous studies consider missed advection as a contributor to the measured energy balance closure gap (Lee 1998; Bernhofer and Vogt 1999; Paw et al. 2000; Lee and Hu 2002; Massman and Lee 2002; Turnipseed et al. 2002; Wilson et al. 2002; Klemm et al. 2006; Kochendorfer and Paw 2011; Higgins et al. 2013; Stoy et al. 2013; Novick et al. 2014; Ringgaard et al. 2014). Only a few studies state that advection is not relevant concerning the energy balance for their inspected site, or it was statistically insignificant (Etzold et al. 2010; Higgins 2012; Varmaghani et al. 2016). This shows that advection is strongly site specific (Yi et al. 2005; Aubinet et al. 2010; Novick et al. 2014).

The number of studies reporting measurement of advective energy fluxes for forested sites is limited. Vertical advective energy fluxes are more often directly assessed (Lee 1998; Bernhofer and Vogt 1999; Lee and Hu 2002; Turnipseed et al. 2002; Moderow et al. 2007, 2011; Novick et al. 2014) than horizontal advective energy fluxes (Moderow et al. 2007; Hong et al. 2008; Moderow et al. 2011); this is because the latter requires a complex set-up. Thomas (2011) addressed aspects of horizontal advection of sensible heat in the subcanopy of a forest.

Lee and $\mathrm{Hu}$ (2002) identified vertical advective fluxes as statistically important and hypothesised that contributions of horizontal energy fluxes may be potentially more important. This is accordance with Novick et al. (2014), who only measured vertical advective energy fluxes. Including estimates of vertical advective energy fluxes into the energy balance did not substantially improve energy balance closure for their data set. Therefore, Novick et al. (2014) concluded that horizontal advection is possibly larger than vertical advection. Moderow et al. (2007) report smaller vertical than horizontal sensible heat advection on average. However, Turnipseed et al. (2002) agreed with Lee (1998) that vertical advective fluxes potentially become important under highly convective conditions, whereas horizontal contributions might cancel out. Concerning the magnitude of the advective fluxes during nighttime and daytime, Wilson et al. (2002) suggested that advective energy fluxes contribute to the energy balance gap during nighttime but advective fluxes might be also important during the day.

The aim of this paper was to add further experimental insights to the problem of the energy balance closure gap in relation to sensible and latent heat advection, namely energy transports by the mean wind (Stull 1988). Further aims were to detect a possible relationship between site heterogeneity and magnitude of advective energy fluxes, and to highlight some of the difficulties inherent in determining advective energy fluxes. The study is based on the ADVEX dataset (Feigenwinter et al. 2008). We present results for three ADVEX sites, followed by some general conclusions.

\section{Material and methods}

\subsection{ADVEX sites}

Three ADVEX measurement campaigns took place at three sites across Europe in 2005 and 2006 (Ritten/Renon, Italy; Wetzstein, Germany; Norunda, Sweden). All three sites were part of CarboEurope-IP (CE-IP; Schulze et al. 2010). Table 1 gives an overview of the basic site characteristics of these locations, which is mainly based on Feigenwinter et al. (2008).

All three sites differed in topography (Fig. 1, Table 1) but were covered by coniferous forests (IGBP vegetation type ENF); however, they showed different vertical distribution of plant area density (Fig. 1). The leaf area index (LAI) ranged between 4 and $5.5 \mathrm{~m}^{2} \mathrm{~m}^{-2}$ for Ritten/Renon and was around $4 \mathrm{~m}^{2} \mathrm{~m}^{-2}$ at Wetzstein; LAI ranged between 3 and $6 \mathrm{~m}^{2} \mathrm{~m}^{-2}$ at Norunda. Wetzstein was the most homogenous stand (evenaged) and Ritten/Renon the least homogenous (uneven-aged stand with varying tree heights) (Feigenwinter et al. 2008). The sites also differed in their wind conditions, which also reflected site location, and stand characteristics (partially). Renon exhibited the highest wind velocities, whereas Norunda had the lowest (Fig. 2).

\subsection{ADVEX experiments}

Data from the ADVEX measurement campaign (Feigenwinter et al. 2008) formed the basis for this study. Feigenwinter et al. (2008) give a detailed description of the configuration and we only present a short overview here. The respective experiments took place in 2005 (Ritten/Renon) and 2006 (Wetzstein, Norunda) (Table 1). All three ADVEX experiments shared a similar arrangement (Fig. 1). Four additional towers of differing design (A, B, C, D; Fig. 1) were erected at the respective sites around the main permanent tower. Each of these additional towers had four measurement levels. The measurement heights were $1.5 \mathrm{~m}, 6 \mathrm{~m}, 12 \mathrm{~m}$, and $30 \mathrm{~m}$ above ground level at Ritten/Renon and Norunda; at Wetzstein, they were $1.5 \mathrm{~m}, 4.4 \mathrm{~m}, 8.8 \mathrm{~m}$, and $24 \mathrm{~m}$ above ground level. The three wind components in space (u, east; v, north; w, vertical), air temperature, $\mathrm{CO}_{2}$, and water vapour concentration were measured at these levels. Ultrasonic anemometers $(81000 \mathrm{~V}$ R.M. Young Meteorological Instruments, US; R3 Gill 
Table 1 General site characteristics of the ADVEX sites. DOY refers to day of year

\begin{tabular}{|c|c|c|c|}
\hline & Ritten/Renon (RE) & Wetzstein (WS) & Norunda (NO) \\
\hline Location & $46^{\circ} 35 \mathrm{~N} 11^{\circ} 26 \mathrm{E}$ & $50^{\circ} 27 \mathrm{~N} 11^{\circ} 27 \mathrm{E}$ & $60^{\circ} 05 \mathrm{~N} 17^{\circ} 28 \mathrm{E}$ \\
\hline Elevation & $1735 \mathrm{~m}$ & $782 \mathrm{~m}$ & $45 \mathrm{~m}$ \\
\hline General topographical characteristic & South facing slope $\left(11^{\circ}\right)$ & Situated at a ridge & flat \\
\hline Mean annual temperature & $4.1^{\circ} \mathrm{C}$ & $5.9^{\circ} \mathrm{C}$ & $5.5^{\circ} \mathrm{C}$ \\
\hline Mean annual precipitation & $1010 \mathrm{~mm}$ & $840 \mathrm{~mm}$ & $527 \mathrm{~mm}$ \\
\hline Main wind direction/local wind system & $\begin{array}{l}\text { Local slope wind system } \\
\text { South-south west wind } \\
\quad \text { (upslope, daytime) } \\
\text { North-north west wind } \\
\text { (downslope, nighttime) }\end{array}$ & South-west & $\begin{array}{l}\text { Slight predominance } \\
\text { of south-westerly winds }\end{array}$ \\
\hline Analysed period of ADVEX & Year 2005, DOY $178-258$ & Year 2006, DOY 102-170 & Year 2006, DOY 188-261 \\
\hline References & $\begin{array}{l}\text { Marcolla et al. (2005), } \\
\text { Feigenwinter et al. (2008) }\end{array}$ & $\begin{array}{l}\text { Feigenwinter et al. }(2008)^{\mathrm{a}} \text {, } \\
\text { Rebmann et al. }(2010)\end{array}$ & $\begin{array}{l}\text { Lundin et al. (1999), } \\
\text { Feigenwinter et al. (2008), } \\
\text { Lindroth et al. (2010) }\end{array}$ \\
\hline
\end{tabular}

${ }^{a}$ Reference for ADVEX experiment

Instruments Ltd., UK, only at tower C) measured the three wind components at $20 \mathrm{~Hz}$. Unshielded thermocouples (type E, diameter $75 \mu \mathrm{m}$, Campbell Scientific, Logan, US; sampling rate $0.5 \mathrm{~Hz}$ ) were employed for recording air temperature. Closed path infrared gas analysers (Li6262/7000, LI-COR, Lincoln, US) were used for measuring $\mathrm{CO}_{2}$ and water vapour
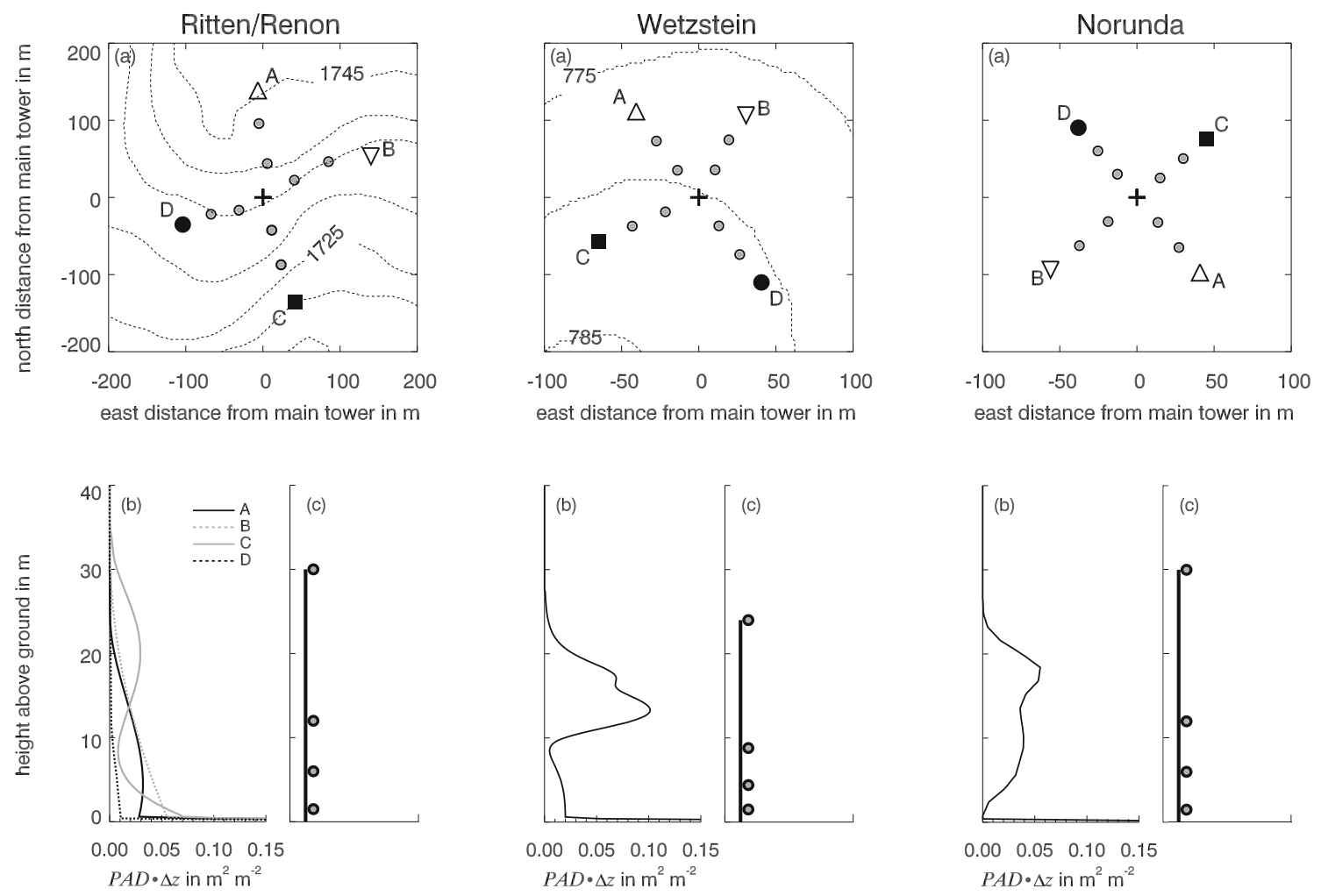

Fig. 1 Site characteristics of the ADVEX sites and location and measurements heights of the ADVEX towers (towers A, B, C, D). (a) Topography and location of towers. Open triangle up, open triangle down, filled quadrangle, and filled circle denote ADVEX towers of different tower designs. Black cross denotes permanent main tower (CarboEurope-IP tower). (b) Profiles of the plant area density (PAD) around the ADVEX towers, calculated for vertical layers of $\Delta z=0.2 \mathrm{~m}$. At Wetzstein and Norunda, PAD information is only available for the surroundings of the main tower. PAD was calculated according to Queck and Bernhofer (2010). (c) Scheme showing the measurements heights at the ADVEX towers. Each dot refers to heights where measurements of wind, air temperature, and water vapour concentration took place 

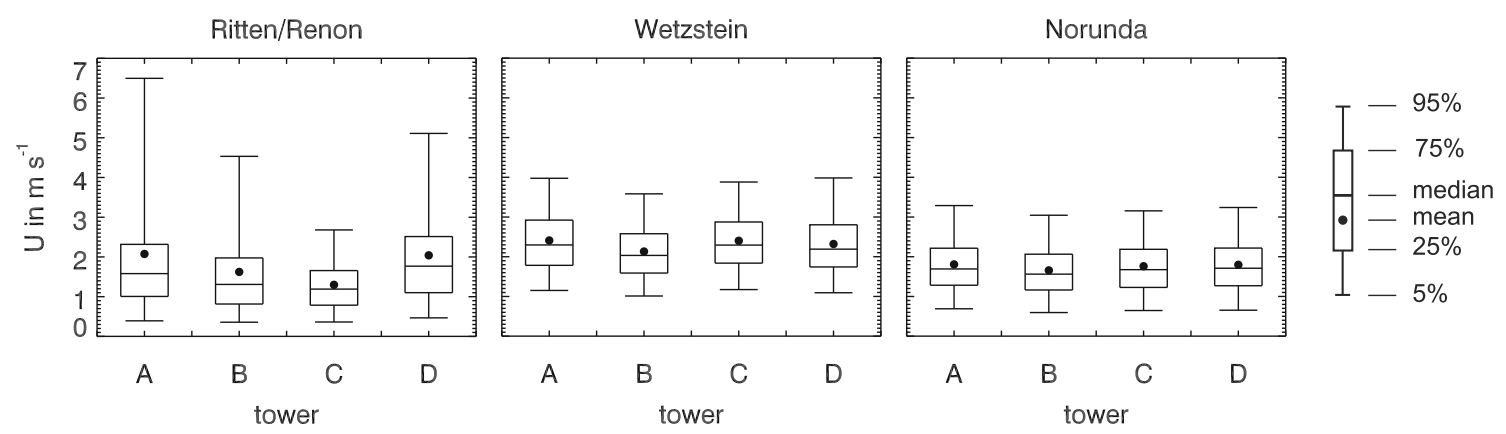

Fig. 2 Distribution of horizontal wind speed U at the uppermost level of each ADVEX tower, i.e. at $30 \mathrm{~m}$ (Ritten/Renon, Norunda) and $24 \mathrm{~m}$ (Wetzstein)

concentration, whereby each measurement level of the ADVEX towers was probed every $160 \mathrm{~s}$. Air temperature at the transect points was measured using unshielded thermocouples (type E, diameter $75 \mu \mathrm{m}$, Campbell Scientific, Logan, US; sampling rate $0.5 \mathrm{~Hz}$ ) at $1.5 \mathrm{~m}$ above ground level. Table 1 indicates the analysed period of each advection experiment.

\subsection{Theory-budget equation}

For a control volume of side length $L$ and height $z_{r}$, the sink/ source strength $S$ involving any scalar $s$ can be written as follows (Finnigan 1999; Feigenwinter et al. 2004; Aubinet et al. 2010):

$$
\begin{gathered}
S(t, x, y, z)=\int_{0}^{z_{r}} \frac{\partial \bar{s}}{\partial t} \mathrm{~d} z+\overline{w^{\prime} z^{\prime}}\left(z_{r}\right)+\int_{0}^{z_{r}} \bar{w} \frac{\partial \bar{s}}{\partial z} \mathrm{~d} z+\frac{1}{4 L^{2}} \int_{-L}^{+L} \int_{-L}^{+L} \int_{0}^{z_{r}}\left(\bar{u}(z) \frac{\partial \bar{s}(z)}{\partial x}+\bar{v}(z) \frac{\partial s(z)}{\partial y}\right) \mathrm{d} x \mathrm{~d} y \mathrm{~d} z \\
I V \\
+\frac{1}{4 L^{2}} \int_{-L}^{+L} \int_{-L}^{+L} \int_{0}^{I I I}\left(\frac{\partial\left(\overline{u^{\prime} s^{\prime}}\right)}{\partial x}+\frac{\partial\left(\overline{v^{\prime} s^{\prime}}\right)}{\partial y}\right) \mathrm{d} x \mathrm{~d} y \mathrm{~d} z \\
V
\end{gathered}
$$

where $t$ denotes time in $s, x, y, z$ the three direction in space (east, north and perpendicular to the surface) and $u, v, w$ the corresponding wind velocities in $\mathrm{m} \mathrm{s}^{-1} \cdot z_{r}$ is also referred to as reference height, which was equal to the uppermost ADVEX measurement level here (Section 2.4). $L$ and $z_{r}$ are given in $\mathrm{m}$. Overbars represent mean values (temporal averaging) and primes are deviations from these mean values. All the terms in Eq. 3 are linked by the control volume of length $L$ and height $z_{r}$. They are separately determined and then added together to give $S$ (source or sink strength).

Term $I$ denotes storage change $\left(\mathrm{F}_{\mathrm{S}}\right)$, term $I I$ vertical turbulent flux at height $z_{r}\left(\mathrm{~F}_{\mathrm{EC}}\right)$, term $I I I$ vertical advection $\left(\mathrm{F}_{\mathrm{VA}}\right)$, term $I V$ horizontal advection $\left(\mathrm{F}_{\mathrm{HA}}\right)$, and term $V$ the horizontal turbulent flux divergence. In the case of sensible heat and latent heat, the terms $I-V$ are in $\mathrm{W} \mathrm{m}^{-2}$. There are discussions about the importance of term $V$ (horizontal flux divergence) (Finnigan 1999; Staebler and Fitzjarrald 2004) but it is commonly assumed that this term is of minor importance (Wyngaard et al. 1971; Lee 1998; Yi et al. 2000). This agrees with Moderow et al. (2007), who revealed a minor importance of the horizontal flux divergence (term $V$ ) for their investigated site. Therefore, we neglect term $V$ in the following.
The sign convention for the fluxes is as follows: positive fluxes denote a transport of energy out of the control volume and negative fluxes denote a transport of energy into the control volume.

\subsection{Calculation methods}

In the case of latent heat, $s$ in Eq. 3 refers to mixing ratio $r$ (mass of water vapour to mass of dry air in $\mathrm{kg} \mathrm{kg}^{-1}$ ) and in the case of sensible heat to potential air temperature $\theta$ in $\mathrm{K}$. Air temperature was converted to potential temperature using Eq. 4 :

$\theta \cong T+\left(g / c_{p}\right) z$

where $T$ is air temperature in $\mathrm{K}, g$ gravitational acceleration, $z$ is height in relation to the reference height in $\mathrm{m}$, and $c_{p}$ is specific heat capacity at constant pressure. The ratio $\left(g / c_{p}\right)$ was taken as $0.0098 \mathrm{~K} \mathrm{~m}^{-1}$ (Stull 1988). The highest ADVEX level at the four towers served as reference height at the respective site.

Mixing ratio (mass of water vapour to mass of dry air) was calculated according to Stull (2000): 
$r=0.622 \frac{e}{(p-e)}$,

where $r$ denotes mixing ratio in $\mathrm{kg} \mathrm{kg}^{-1}$, $e$ partial pressure of water vapour in $\mathrm{hPa}$, and $p$ air pressure in $\mathrm{hPa}$. The number 0.622 is the ratio of the gas constants for dry air to that for water vapour. Equation 5 requires measured level-specific air pressure, which was not available. These pressure data were obtained via barometric relationship using the available air pressure measurement of the respective site. Equation 5 used level-specific air pressure and water vapour pressure. Furthermore, level-specific air density and air temperature was used to convert measured water vapour concentration to water vapour pressure and respective molar mass.

Vertical advection was calculated following the procedure outlined in Feigenwinter et al. (2008), which is based on the approach of Lee (1998). Vertical advection was separately determined for each of the four ADVEX towers per site, whereas $\theta$ and $r$ were linearly interpolated using a layer thickness of $0.5 \mathrm{~m}$ before calculating vertical differences according to Lee (1998). The resulting vertical advection (term III of Eq. 3 ) was the average for all tower-specific vertical advection estimates for each time step. The average for all towers included estimates for at least three towers. If less than three towers were available, the corresponding half hour was labelled with an error code.

Prior to averaging vertical advection horizontally, mean values of vertical advection of sensible heat of individual towers ranged from $-24.0 \mathrm{~W} \mathrm{~m}^{-2}$ to $8.0 \mathrm{~W} \mathrm{~m}^{-2}$ ($7.0 \mathrm{~W} \mathrm{~m}^{-2}$ to $-3.0 \mathrm{~W} \mathrm{~m}^{-2} ; 0.0 \mathrm{~W} \mathrm{~m}^{-2}$ to $3.0 \mathrm{~W} \mathrm{~m}^{-2}$ ) at Ritten/Renon (Wetzstein, Norunda). Mean values of latent heat advection of individual tower ranged from $-3.0 \mathrm{~W} \mathrm{~m}^{-2}$ to $-12.0 \mathrm{~W} \mathrm{~m}^{-2}$ ( $-0.5 \mathrm{~W} \mathrm{~m}^{-2}$ to $2.0 \mathrm{~W} \mathrm{~m}^{-2} ;-1.0 \mathrm{~W} \mathrm{~m}^{-2}$ to $0.5 \mathrm{~W} \mathrm{~m}^{-2}$ ) at Ritten/Renon (Wetzstein, Norunda). Appendix A gives further details concerning comparison of towerspecific vertical advection estimates.

Determination of the mean vertical velocity $(\bar{w})$ followed the approach of Wilczak et al. (2001) and used rotation matrices as noted in Rebmann et al. (2012). Here, 18 wind sectors (sector size $20^{\circ}$, starting from $350^{\circ}$ ) were used. Time intervals with at least one of the following characteristics were excluded for determining rotation angles: $U<1 \mathrm{~m} \mathrm{~s}^{-1}, \mathrm{w}>1 \mathrm{~m} \mathrm{~s}^{-1}$, angle of attack $>20^{\circ}$, where $U$ refers to horizontal wind speed and $\mathrm{w}$ to measured vertical wind speed.

Horizontal advection was obtained using the approach of Feigenwinter et al. (2008). This approach utilised bilinear interpolation yielding gridded horizontal wind components $\mathrm{u}$ (east, $x$-direction) and $\mathrm{v}$ (north, $y$-direction) temperatures and water vapour concentrations based on the measurements of the four ADVEX towers. The grid had a spatial resolution of $10 \mathrm{~m}$. Horizontal gradients of temperature (water vapour concentration) in the direction of $x$ (east) and $y$ (north), respectively, were obtained by linear interpolation of the temperature (water vapour concentration) differences between grid points in the respective direction. Based on these gridded gradients and gridded horizontal wind components $\mathrm{u}$ (east) and $\mathrm{v}$ (north), horizontal advection was calculated for each grid point and then averaged over the respective layer. The resulting horizontal advection of each time step was computed by integration over the height of the control volume (term $I V$ of Eq. 3). Prior to gridding, the vertical profiles were linearly interpolated using a layer thickness of $0.5 \mathrm{~m}$. For further information, see Feigenwinter et al. (2008).

Vertical turbulent fluxes of sensible and latent heat are based on CarboEurope-IP measurements (Schulze et al. 2010) at the main tower of the respective site and were obtained via Eddy covariance (Aubinet et al. 2012a). They were taken from Moderow et al. (2009). Please note that these measurements took place above the uppermost ADVEX level. We assume that possible heat storage changes within the layer in between are very small and therefore negligible, and further assume that all measurements above the respective canopy took place within the constant flux layer. See Moderow et al. (2009) for details of the respective measurement configuration and post-processing.

Estimates of available energy and their uncertainty bounds were taken from Moderow et al. (2009). Available energy encompassed net radiation, soil heat flux (including heat storage changes between soil heat flux plate and soil surface), and heat storage changes. Heat storage changes included sensible and latent heat storage change, heat storage change in biomass, and heat storage change due to photosynthesis. For a detailed description of the calculation of the available energy and its uncertainty bounds, see Moderow et al. (2009).

Atmospheric stability was evaluated using measurement height (z) divided by the Monin-Obukhov-Length (L) and was calculated based on data of the EC system used for obtaining vertical turbulent fluxes of sensible and latent heat (Moderow et al. 2009). Furthermore, we used the Richardson number (Ri) to assess atmospheric stability within the canopy. The Ri was calculated as described in Oliveira et al. (2013) and van Gorsel et al. (2011) and is shown in Eq. 6:

$R i_{\text {can }} \equiv\left(\frac{g \Delta z}{\Theta}\right) \frac{\theta_{30}-\theta_{6}}{\left(U_{30}-U_{6}\right)^{2}}$,

where $U$ denotes horizontal wind speed in $\mathrm{m} \mathrm{s}^{-1}, \theta$ potential temperature in $\mathrm{K}, g$ gravitational acceleration in $\mathrm{m} \mathrm{s}^{-2}, \Delta z$ layer thickness between upper and lower measurement level in $\mathrm{m}$, and $\Theta$ reference temperature in $\mathrm{K}$ taken from the upper measurement level. Index ' 30 ' (' 6 ') denotes measurement levels at 30 (6) $\mathrm{m}$ above ground level at Ritten/Renon and Norunda. The corresponding measurement levels were $24 \mathrm{~m}$ and $4.4 \mathrm{~m}$ above ground level at Wetzstein. Inputted data of $\theta$, $\Theta$, and $\mathrm{U}$ were averaged over all ADVEX towers and the respective measurement levels. 
The following statistical measures were used to analyse energy balance closure: simple linear regression and energy balance ratio (EBR), as given in Eq. 7:

$E B R=\frac{\sum(H+L E)}{\sum(A E)}$,

where EBR denotes energy balance ratio, $\mathrm{H}$ sensible heat flux, LE latent heat flux, and AE available energy. $\mathrm{H}, \mathrm{LE}$, and $\mathrm{AE}$ are in $\mathrm{W} \mathrm{m}^{-2}$, while EBR is dimensionless.

Time-intervals fulfilling at least one of the following criteria were excluded from analyses: precipitation greater than $0 \mathrm{~mm}$; relative humidity greater or equal to $97.5 \%$. This was done to minimise the influence of possibly wetted sensor surfaces and involved errors.

Global radiation (RG) was used to distinguish between nighttime and daytime. Half-hourly values with RG greater than $5 \mathrm{~W} \mathrm{~m}^{-2}$ were termed daytime, and half-hourly values with $\mathrm{RG}$ equal to $0 \mathrm{~W} \mathrm{~m}^{-2}$ denote nighttime.

All calculations were done on a half-hourly basis.

\subsubsection{Sloped site Ritten/Renon}

Sloped sites deserve special attention in studies devoted to the energy exchange between the earth's surface and the atmosphere because they clearly deviate from ideal surfaces in terms of micrometeorological studies (horizontal, homogeneous, unlimited fetch). Therefore, there is an ongoing discussion on the determination of energy balance components, which addresses the measurement of the available energy (Whiteman et al. 1989; Matzinger et al. 2003; Leuning et al. 2012; Serrano-Ortiz et al. 2016; Wohlfahrt et al. 2016) as well as the measurement of turbulent heat fluxes (Geissbühler et al. 2000; Christen et al. 2001; Stiperski and Rotach 2016).

Studies dealing with the correct measurement of net radiation at sloped sites have concluded that a slope-parallel measurement arrangement should be used because inclination of a surface alters its radiation gain (Whiteman et al. 1989; Matzinger et al. 2003; Holst et al. 2005; Leuning et al. 2012; Serrano-Ortiz et al. 2016; Wohlfahrt et al. 2016). Therefore, we corrected horizontally measured net radiation to account for this altered radiation gain at the sloped site (Ritten/Renon, slope of $11^{\circ}$ ). Correction of net radiation not measured parallel to the surface was calculated according to a procedure described by Goldberg (1999). The required separate estimates of diffuse and direct solar radiation were obtained following a procedure as outlined by Collares-Pereira and Rabl (1979) because no separate measurements of these two radiation fluxes were available. The required extra-terrestrial radiation was computed following a procedure described by Gassel (1997).

The application of EC methods requires very fast measurements of the three wind components $(\mathrm{u}, \mathrm{v}, \mathrm{w})$ in the three directions of space $(\mathrm{x}, \mathrm{y}, \mathrm{z})$. Vertically-installed sonic anemometers are commonly used for this, even on sloping terrain. Only a few studies have applied a slope-normal configuration or compared measurements of vertically mounted to slopenormal mounted sonics (Geissbühler et al. 2000; Christen et al. 2001; Nadeau et al. 2013; Oldroyd et al. 2016; Stiperski and Rotach 2016). A slope-normal orientation has the advantage of reducing flow distortion, which is caused by the sonic itself compared with a vertical configuration (Geissbühler et al. 2000; Christen et al. 2001; Stiperski and Rotach 2016). Stiperski and Rotach (2016) compared measurements of sensible heat flux based on a vertically and a slope-normal mounted sonic on a slope of $27^{\circ}$. They found small but statistically significant differences between both setups for radiatively driven days. However, there was no statistical significance for days not-radiatively driven. Based on wind tunnel experiments, Christen et al. (2001) stated that angles of attack which deviate less than $10^{\circ}$ from the horizontal plane are preferable because this results in more reliable measurements. Geissbühler et al. (2000) investigated the difference between the two set-ups on a sloped site of $23^{\circ}$. According to their conclusion, a slope-normal position of a sonic is ideal for the investigation of single flux events, while they detected no significant differences in the mean and variances of turbulent fluxes.

Ritten/Renon is on a slope of $11^{\circ}$, which is clearly less than the slope of the inspected site of Geissbühler et al. (2000), and a vertically mounted sonic was used for obtaining turbulent fluxes of sensible and latent heat flux. Therefore, we assume that using these turbulent heat fluxes is justified because we are interested in balances and investigated longer time-periods than those of Geissbühler et al. (2000) and Stiperski and Rotach (2016).

Feigenwinter et al. (2010b) investigated the slope wind systems of Ritten/Renon based on the ADVEX dataset using the same approach as in this publication. They demonstrated that this approach is capable of capturing the wind pattern and connected advective flow pattern of this site and further showed that the transport took place parallel to the slope.

\section{Results and discussion}

\subsection{Vertical advective fluxes of sensible and latent heat}

Figure 3 shows diurnal courses of vertical sensible heat advection $\left(\mathrm{F}_{\mathrm{VA}, \mathrm{H}}\right)$. Wetzstein showed weakly developed diurnal courses with a tendency towards larger negative values during nighttime and towards small positive values during day; such well-marked tendencies were not observed at Norunda and Ritten/Renon. Generally, diurnal courses confirmed the pattern shown by Moderow et al. (2011), but were not identical. 

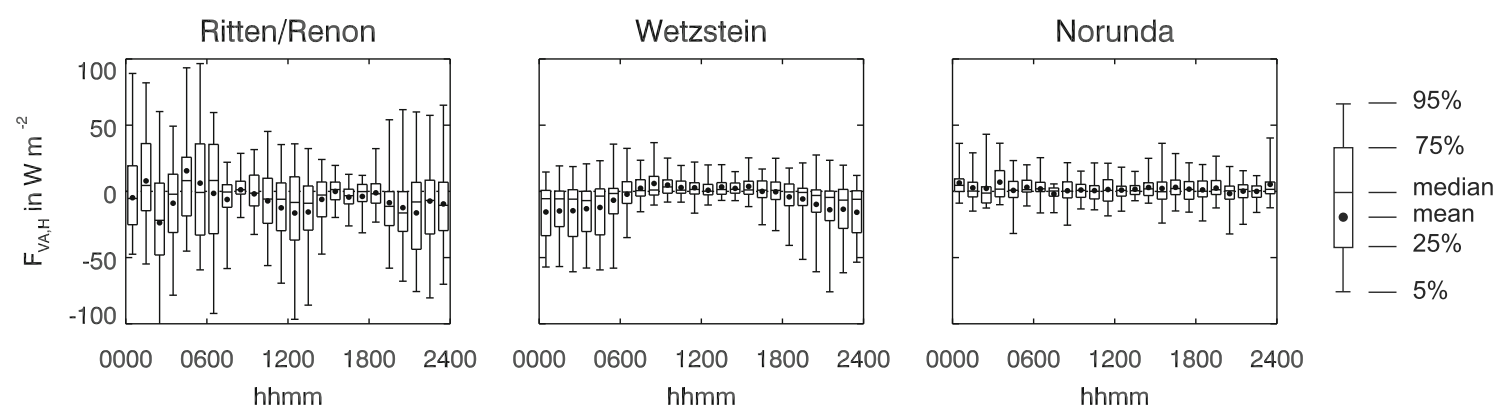

Fig. 3 Diurnal courses of vertical sensible heat advection $\left(\mathrm{F}_{\mathrm{VA}, \mathrm{H}}\right)$ as box plots based on half-hourly values

The reason for this was twofold. Firstly, $\bar{w}$ was newly calculated using deviating wind sectors and thresholds, although it should be noted that mean diurnal behaviour of $\bar{w}$ changed only slightly (not shown). This highlighted the sensitivity of vertical advective fluxes to the way $\bar{w}$ is determined. Secondly, Moderow et al. (2011) excluded distinct wind sectors (Wetzstein) and synoptic situations (Ritten/Renon) in their analyses, whereas we included them.

Absolute values and scatter of vertical advective fluxes of sensible heat tended to follow the ranking of heterogeneity of the sites; Ritten/Renon, as the least homogenous site, exhibited the largest values and scatter, whereas Norunda (the most homogenous site) exhibited the smallest values and no distinct diurnal course.

Resulting vertical latent heat advection $\left(\mathrm{F}_{\mathrm{VA}, \mathrm{LE}}\right)$ is shown in Fig. 4. F VA,LE $_{\text {Le }}$ did not show a well-developed diurnal course at any site. The most heterogeneous site (Ritten/Renon) again showed the largest fluxes, whereas $\mathrm{F}_{\mathrm{VA}, \mathrm{LE}}$ was of comparable magnitude at Norunda and Wetzstein.

It is normally assumed that advective fluxes are small during the day (turbulent conditions, unstable atmospheric stratification) and larger advective fluxes occur at nighttime (suppressed/no turbulence, stable atmospheric stratification). The obtained data of vertical advective fluxes only marginally reflected this. An analysis of $\mathrm{F}_{\mathrm{VA}, \mathrm{H}}$ and $\mathrm{F}_{\mathrm{VA}, \mathrm{LE}}$ in relation to friction velocity $\left(u_{*}\right)$ (conducted separately for day and night) showed that these obtained fluxes were not sensitive to $u_{*}$ (except $\mathrm{F}_{\mathrm{VA}, \mathrm{H}}$ at Wetzstein). Here, $\mathrm{F}_{\mathrm{VA}, \mathrm{H}}$ changed in sign and tended to larger negative values below $u_{*}=0.3 \mathrm{~m} \mathrm{~s}^{-1}$.

Three classes of atmospheric stability (stable: $z / L>$ $0.05 \mathrm{~m} \mathrm{~m}^{-1}$, unstable: $z / L<-0.05 \mathrm{~m} \mathrm{~m}^{-1}$, and neutral in between) were used to evaluate the behaviour of vertical advective fluxes in relation to atmospheric stability separately for day and night. Similar to the dependency on $u_{*}$, vertical advective fluxes only showed a clear dependency on atmospheric stratification in the case of $F_{\mathrm{VA}, \mathrm{H}}$ at Wetzstein. Here, $\mathrm{F}_{\mathrm{VA}, \mathrm{H}}$ changed in sign and tended to larger negative values when approaching strongly stable conditions during both night and day. No clear dependencies could be detected for the other two sites. Two factors might contribute to this: firstly, the uncertainty in determining mean vertical velocity, and secondly, the chosen approach for determining mean vertical differences. We evaluated atmospheric stability using the measure $z / L$ and the $\mathrm{Ri}$ (Eq. 6) to investigate this further. A comparison showed that the Ri indicated stable conditions more frequently than the measure $z / L$, suggesting that a possible stable layer within the canopy suppresses vertical transport. Therefore, it is possible that an exchange is calculated which does not occur in reality over the whole vertical extent of the stand; this is because measurements are used which were taken above, in, and below the canopy. At Wetzstein, this hypothesis is supported by the results of Zeri (2008); these revealed a decoupling of the flow above the canopy from the flow below the canopy for low values of $u_{*}$ (typically nighttime conditions). Absolute values of vertical advection at all sites were not sensitive to wind direction.

At Ritten/Renon, low vertical sensible heat advection was observed in the morning and in the late afternoon (Fig. 3, Fig. 5). These values coincided with times
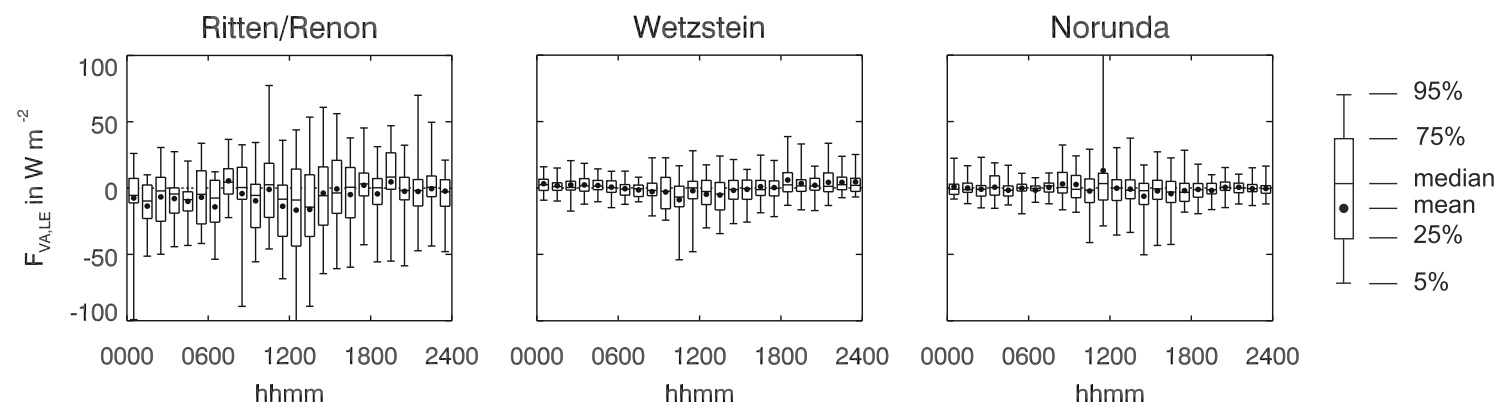

Fig. 4 Diurnal courses of vertical latent heat advection $\left(\mathrm{F}_{\mathrm{VA}, \mathrm{LE}}\right)$ as box plots based on half-hourly values 
Fig. 5 Diurnal courses of vertical differences in potential velocity, vertical advection of sensible heat, and wind direction, half-hourly values grouped by hour. Grey areas denote times of sunrise and sunset during the investigated period temperature, mean vertical
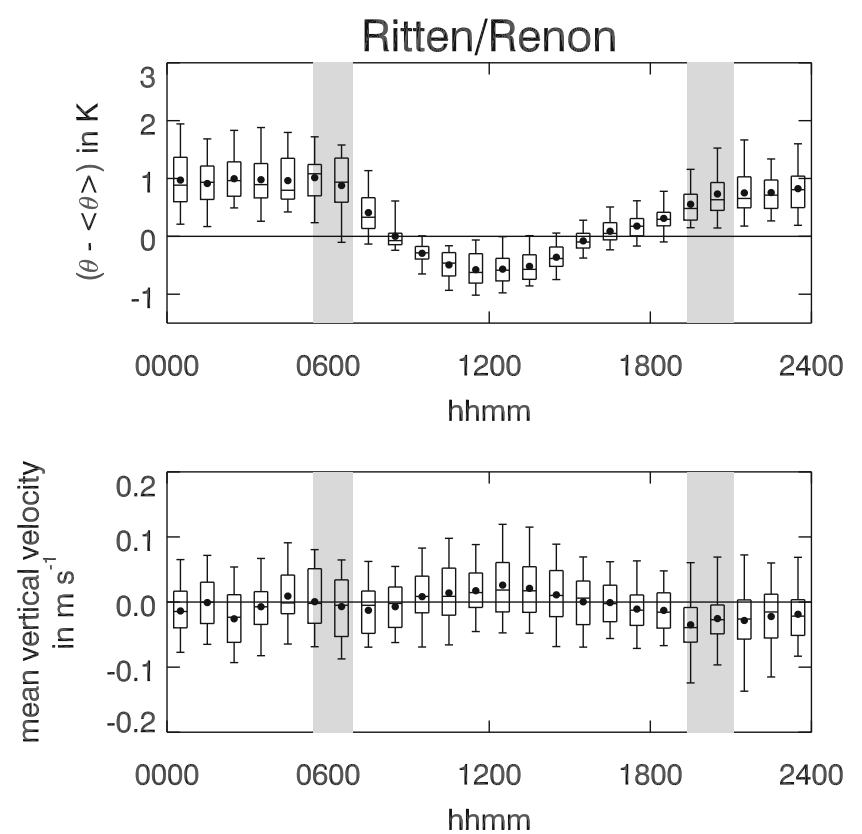

$-95 \%$
$-75 \%$
$-\begin{aligned} & \text { median } \\ & - \text { mean } \\ & -25 \% \\ & -5 \%\end{aligned}$
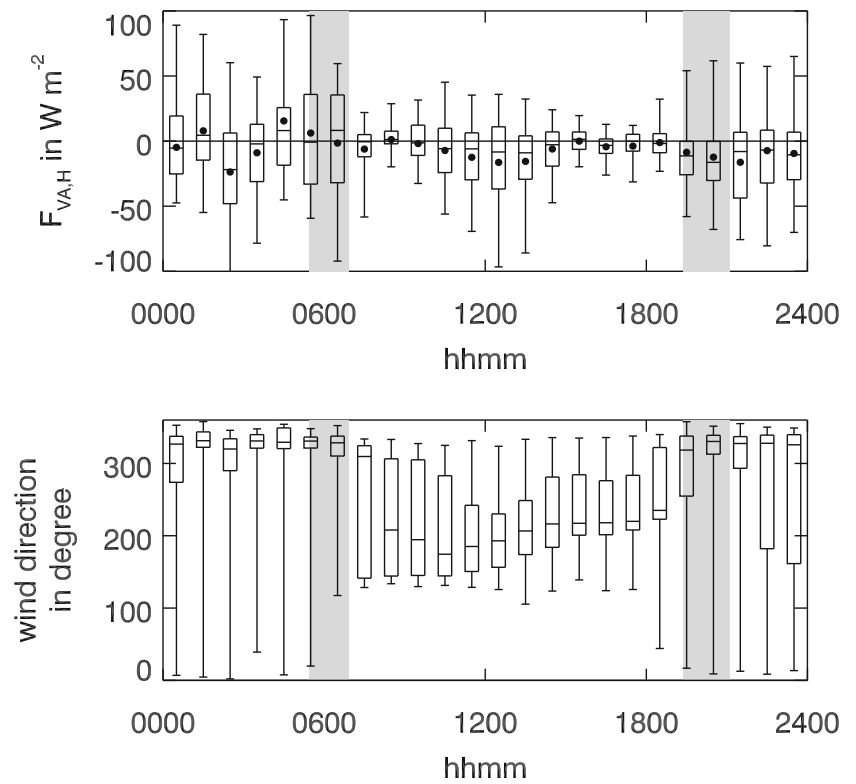

where vertical differences changed in sign (Fig. 5). Northerly winds dominated during the night, whereas southerly winds dominated during the day (Feigenwinter et al. 2010b; Fig. 7). The low advection estimates in the morning coincided with the transition of the nighttime downslope flow to daytime upwind flow. However, the change between a daytime and nighttime regime occurred more gradually in the evening compared with the morning. Low advective estimates mainly occurred before the evening transition of the slope flow. Therefore, low advective estimates after sunrise are due to small vertical differences and a change in the slope flow, whereas low advective estimates before sunset are mainly due to small vertical differences.

\subsection{Horizontal advective fluxes of sensible and latent heat}

Figure 6 shows diurnal variations of horizontal advection of sensible heat $\left(\mathrm{F}_{\mathrm{HA}, \mathrm{H}}\right)$. All subplots have the same y-axis range to facilitate better comparison between sites. Horizontal sensible heat advection $\left(\mathrm{F}_{\mathrm{HA}, \mathrm{H}}\right)$ at Ritten/Renon exhibited a clear diurnal course with negative fluxes during the night and positive fluxes during the day. The obtained advective fluxes of $\mathrm{F}_{\mathrm{HA}, \mathrm{H}}$ were large for this site. During nighttime, large values of $\mathrm{F}_{\mathrm{HA}, \mathrm{H}}$ were mainly connected with northerly winds (approximately downslope direction), whereas $\mathrm{F}_{\mathrm{HA}, \mathrm{H}}$ was mainly connected with southerly winds (approximately upslope direction) during daytime (Fig. 7). Thus, $\mathrm{F}_{\mathrm{HA}, \mathrm{H}}$ was connected 

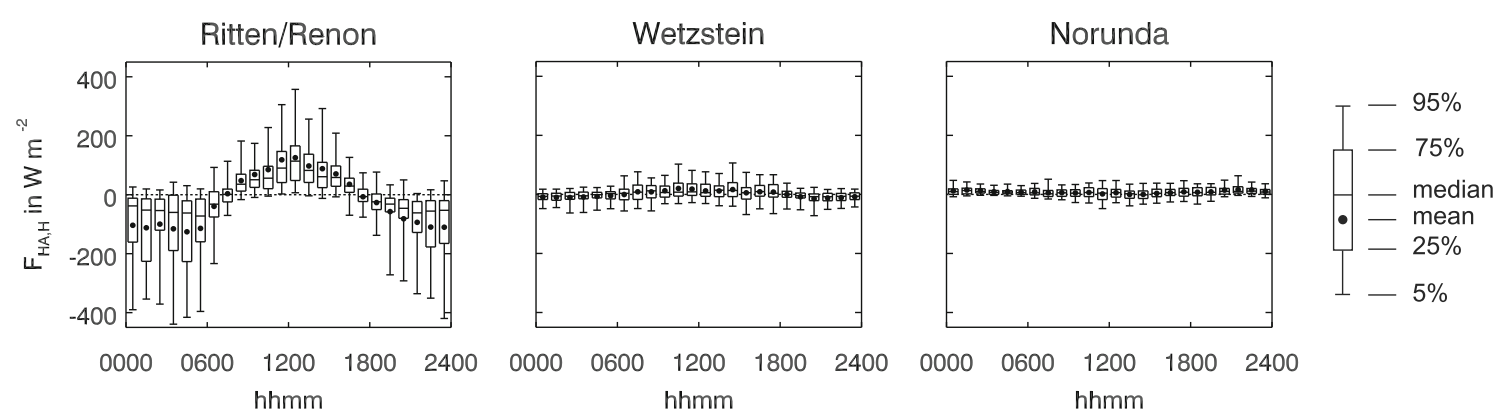

Fig. 6 Diurnal courses of horizontal sensible heat advection $\left(\mathrm{F}_{\mathrm{HA}, \mathrm{H}}\right)$ as box plots based on half-hourly values

with a slope flow phenomenon at this site, as shown by Feigenwinter et al. (2010b) in the case of $\mathrm{CO}_{2}$-advection.

$\mathrm{F}_{\mathrm{HA}, \mathrm{H}}$ at Wetzstein showed a similar diurnal course to $\mathrm{F}_{\mathrm{HA}, \mathrm{H}}$ at Ritten, although absolute values were smaller than $\mathrm{F}_{\mathrm{HA}, \mathrm{H}}$ at Ritten. $\mathrm{F}_{\mathrm{HA}, \mathrm{H}}$ at Norunda did not show a marked diurnal course. A large scatter was apparent for all three sites. Generally, diurnal courses reflected the pattern shown by Moderow et al. (2011), although distinct wind sectors (synoptic situations) were not excluded in this study at Wetzstein and Ritten/Renon. If distinct synoptic situations (strong winds from either the South or North penetrating deep into the canopy; Feigenwinter et al. (2008)) were excluded at Ritten/Renon, then the amplitude of the respective diurnal courses of $\mathrm{F}_{\mathrm{HA}, \mathrm{H}}$ decreased and large values were obtained less often. This was also true at Wetzstein if distinct wind sectors (across ridge situations) were excluded, indicating that these special situations enhanced advection. Regarding horizontal advection, $\mathrm{F}_{\mathrm{HA}, \mathrm{H}}$ at Ritten/Renon exhibited the largest values and scatter, Norunda showed the smallest values, with Wetzstein in between. Ritten/Renon was the most heterogeneous site and Norunda the least heterogeneous. Therefore, this comparison also reveals the effects of different heterogeneities.

Fig. $7 \mathrm{~F}_{\mathrm{HA}, \mathrm{H}}$ at Ritten/Renon as a function of wind direction based on half hourly values (daytime: $n=1598$; nighttime: $n=723$ ). Outer circles denote $15 \%$ of total values
Figure 8 shows the diurnal courses of latent heat advection $\left(\mathrm{F}_{\mathrm{HA}, \mathrm{LE}}\right)$. The graphs use the same scaling for $\mathrm{F}_{\mathrm{HA}, \mathrm{H}}$ to facilitate comparison with $\mathrm{F}_{\mathrm{HA}, \mathrm{H}}$ and between sites. The obtained fluxes were mainly positive at Ritten/Renon and Wetzstein over the whole day, indicating a removal of moisture from the control volume. Norunda showed mostly smaller fluxes which were not characterised by a predominance of a distinct flux direction. The large scatter of obtained advective fluxes was striking, with all three sites showing this characteristic. Scatter was partly even greater than for $\mathrm{F}_{\mathrm{HA}, \mathrm{H}}$. This scatter was most unevenly distributed throughout the day at Norunda. We hypothesised that this pattern of scatter, which indicated frequently occurring very large latent heat advection, is caused by the water vapour concentration measurements. An inspection of the standard deviations of halfhourly water vapour concentration measurements $\left(\sigma_{\mathrm{H} 2 \mathrm{O}}\right)$ showed the largest values as well as the largest scatter at Norunda, whereas the smallest values as well as scatter of $\sigma_{\mathrm{H} 2 \mathrm{O}}$ occurred at Wetzstein. Additionally, $\sigma_{\mathrm{H} 2 \mathrm{O}}$ exhibited almost no variation with friction velocity $\left(u_{*}\right)$ at Wetzstein, whereas $\sigma_{\mathrm{H} 2 \mathrm{O}}$ clearly increased with decreasing $u_{*}$ at Norunda. Furthermore, at Norunda we found larger values as well as scatter of $\sigma_{\mathrm{H} 2 \mathrm{O}}$ for stable stratification (typical

\section{Ritten/Renon}

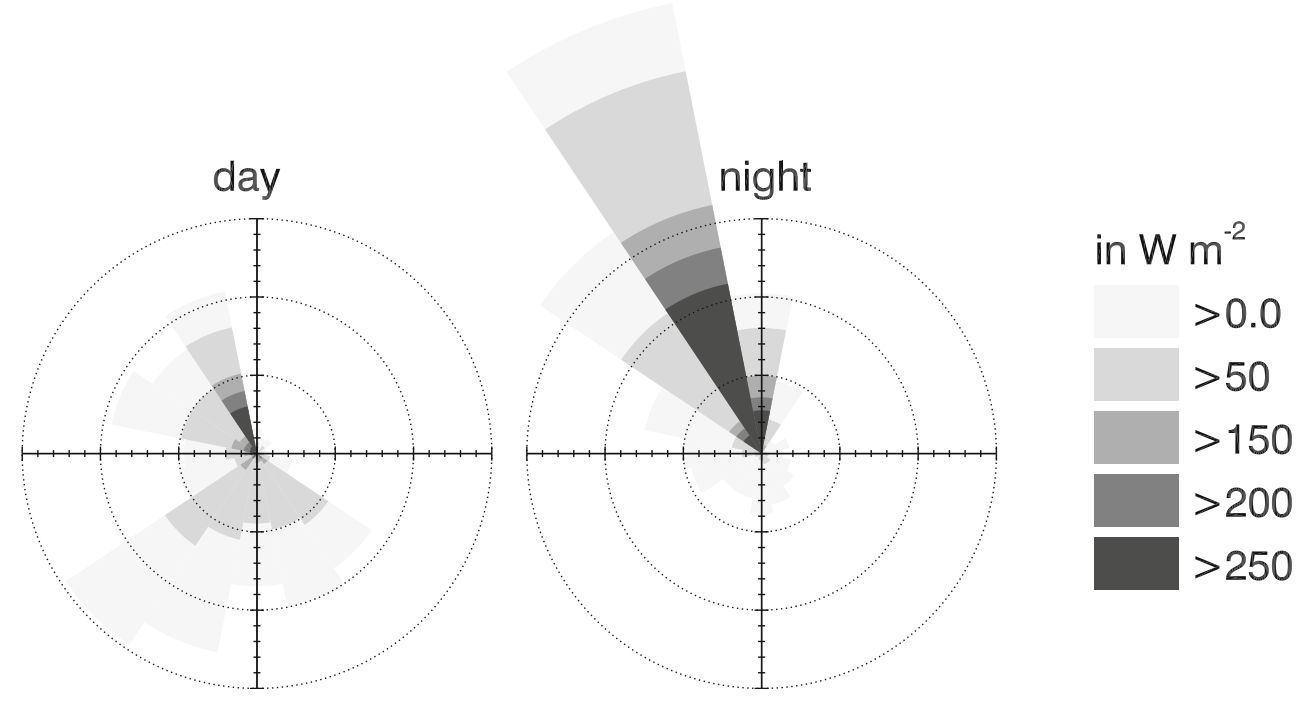



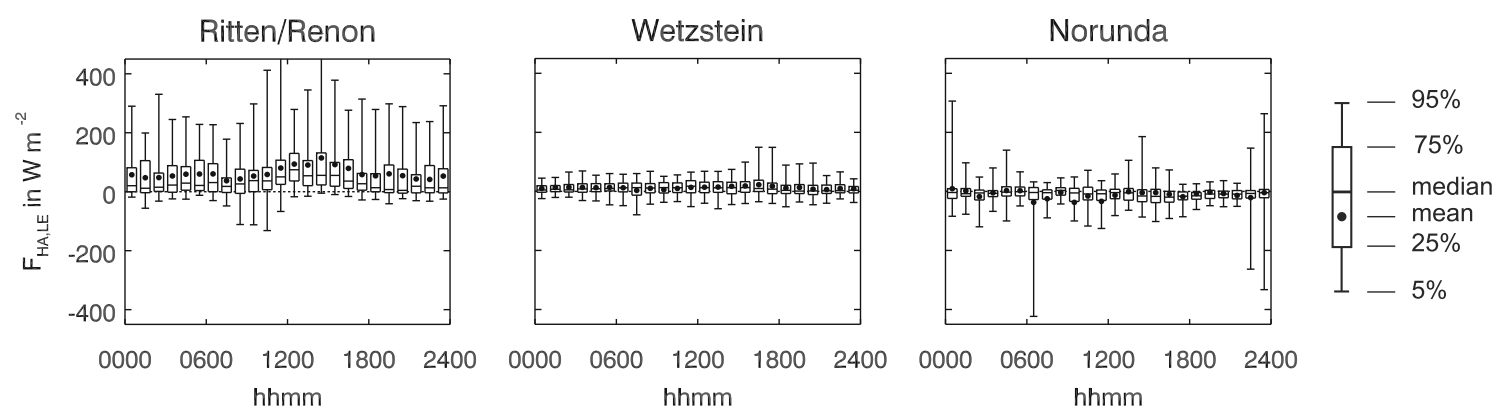

Fig. 8 Diurnal courses of horizontal latent heat advection $\left(\mathrm{F}_{\mathrm{HA}, \mathrm{LE}}\right)$ as box plots based on half-hourly values.

nighttime condition) than for unstable conditions. Therefore, we assume that the water vapour-concentration measurements were more affected by the applied discontinuous sampling strategy at Norunda than at Wetzstein. The discontinuous sampling strategy can result in large not necessarily physical fluxes, as demonstrated by, for example, Siebicke et al. (2011), Siebicke et al. (2012) and Marcolla et al. (2014). The large fluxes of $\mathrm{F}_{\mathrm{HA}, \mathrm{LE}}$ did not coincide with reported large $\mathrm{CO}_{2}$-advection at Norunda (Feigenwinter et al. 2010a). Ritten/ Renon was like Norunda, with $\sigma_{\mathrm{H} 2 \mathrm{O}}$ tending to increase with decreasing $u_{*}$ and with increasing stable atmospheric stratification. This, in combination with larger horizontal wind speeds compared with the other two sites, also resulted in frequently large $\mathrm{F}_{\mathrm{HA}, \mathrm{LE}}$. Given the uncertainty inherent in the water vapour concentration measurement, only a very cautious interpretation of $\mathrm{F}_{\mathrm{HA}, \mathrm{LE}}$ in relation to site heterogeneity was possible. However, the obtained results suggested that heterogeneous sites might be more influenced by $\mathrm{F}_{\mathrm{HA}, \mathrm{LE}}$ than homogenous sites.

$\mathrm{F}_{\mathrm{HA}, \mathrm{H}}\left(\mathrm{F}_{\mathrm{HA}, \mathrm{LE}}\right)$ clearly increased with increasing $u_{*}$ above a threshold of $u_{*}$ around $0.4 \mathrm{~m} \mathrm{~s}^{-1}\left(0.3 \mathrm{~m} \mathrm{~s}^{-1}\right)$ at Ritten/Renon during day (nighttime). This also was detectable at Wetzstein for daytime conditions but not as clearly as for Ritten/Renon. Advective horizontal fluxes at Norunda did not show a welldefined dependency on $u_{*}$. All sites tended to exhibit larger horizontal advection when approaching slightly stable or slightly unstable conditions.

We found that horizontal advective fluxes were larger than vertical advective fluxes. This supports the hypothesis outlined by Lee and $\mathrm{Hu}$ (2002) that horizontal advection may be larger than vertical advection, as well as a similar conclusion by Novick et al. (2014). Moderow et al. (2007) obtained a similar result for an old spruce forest in Germany, but only assessed sensible heat advection.

\subsection{Energy budgets and closure}

We only present a cautious interpretation of corresponding budgets here because of weaknesses and limitations in calculating advective fluxes, which became apparent when inspecting diurnal courses and relationships to turbulence and atmospheric stratification. Firstly, mean values of sensible and latent heat budgets with and without consideration of advective fluxes are presented (Table 2), and secondly the possible influence of advective fluxes on energy balance closure is discussed. In general, the results for Ritten/Renon and Wetzstein were similar, whereas Norunda was different.

Mean values of advective fluxes (Table 2) indicate that vertical advection $\left(\mathrm{F}_{\mathrm{VA}}\right)$ was on average smaller than horizontal advection $\left(\mathrm{F}_{\mathrm{HA}}\right)$, as diurnal courses have already suggested. This corresponds to other studies for sensible heat advection (Moderow et al. 2007) and studies concerning $\mathrm{CO}_{2}$ advection (Feigenwinter et al. 2004; Feigenwinter et al. 2008; Zeri et al. 2010). $\mathrm{F}_{\mathrm{HA}}$ and $\mathrm{F}_{\mathrm{VA}}$ did not cancel each other out for sensible or latent heat at any of the sites. This partly contrasts to the results of Hong et al. (2008), where $\mathrm{F}_{\mathrm{HA}}$ and $\mathrm{F}_{\mathrm{VA}}$ of latent heat cancelled each other out for the layer above the canopy.

During nighttime, advective fluxes increased the total sensible heat flux on average at Ritten/Renon and Wetzstein (Table 2), adding energy to the control volume. At both sites, this qualitatively reflected the change in latent heat flux, which was also increased overall by advective fluxes during nighttime. This led to the hypothesis that additional energy from sensible heat advection facilitates higher evaporation during nighttime. Furthermore, advective fluxes changed the budget of sensible heat and latent heat in relative terms (in relation to $\mathrm{F}_{\mathrm{EC}}$ ) more during nighttime than during the day at these two sites. However, in relative terms, the change due to advective fluxes was larger for the latent heat budget than for the sensible heat budget; this is because the turbulent latent heat fluxes were usually small during nighttime. Absolute values of latent heat advection could not be considered negligible. This result did not confirm the statement of Paw et al. (2000), who speculated that the latent heat budget would be less sensitive to errors caused by advection during nighttime. When inspecting daytime and nighttime together, the results from Ritten/Renon and Wetzstein qualitatively agreed. The budget of sensible heat decreased when including advective fluxes, whereas the budget of latent heat increased. The changes in the respective budgets did not compensate each other.

The results for Norunda differed from the results for Ritten/ Renon and Wetzstein, and no consistent behaviour was seen 
Table 2 Mean values of surface fluxes (based on half-hourly values) including and excluding advective fluxes for nighttime $\left(\mathrm{RG}=0 \mathrm{~W} \mathrm{~m}^{-2}\right)$, daytime $\left(\mathrm{RG}>5 \mathrm{~W} \mathrm{~m}^{-2}\right)$, and whole day. The ratio $\left(\mathrm{F}_{\mathrm{EC}}+\mathrm{F}_{\mathrm{HA}}+\mathrm{F}_{\mathrm{VA}}\right) / \mathrm{F}_{\mathrm{EC}}$ is based on absolute values of the sum $\mathrm{F}_{\mathrm{EC}}+\mathrm{F}_{\mathrm{HA}}+\mathrm{F}_{\mathrm{VA}}$ and $\mathrm{F}_{\mathrm{EC}}$, respectively. $\mathrm{n}$ denotes the number of considered half-hourly values

\begin{tabular}{|c|c|c|c|c|c|c|c|c|c|c|c|}
\hline & \multirow[b]{2}{*}{$n$} & \multicolumn{5}{|c|}{ sensible heat flux } & \multicolumn{5}{|c|}{ latent heat flux } \\
\hline & & $\begin{array}{l}\mathrm{F}_{\mathrm{EC}} \\
\mathrm{W} \mathrm{m}^{-}\end{array}$ & $\mathrm{F}_{\mathrm{HA}}$ & $\mathrm{F}_{\mathrm{VA}}$ & $\begin{array}{l}\mathrm{F}_{\mathrm{EC}}+\mathrm{F}_{\mathrm{HA}} \\
+\mathrm{F}_{\mathrm{VA}}\end{array}$ & $\begin{array}{l}\left(\mathrm{F}_{\mathrm{EC}}+\mathrm{F}_{\mathrm{HA}}\right. \\
\left.+\mathrm{F}_{\mathrm{VA}}\right) / \mathrm{F}_{\mathrm{EC}} \\
\%\end{array}$ & $\begin{array}{l}\mathrm{F}_{\mathrm{EC}} \\
\mathrm{W} \mathrm{m}^{-2}\end{array}$ & $\mathrm{~F}_{\mathrm{HA}}$ & $\mathrm{F}_{\mathrm{VA}}$ & $\begin{array}{l}\mathrm{F}_{\mathrm{EC}}+\mathrm{F}_{\mathrm{HA}} \\
+\mathrm{F}_{\mathrm{VA}}\end{array}$ & $\begin{array}{l}\left(\mathrm{F}_{\mathrm{EC}}+\mathrm{F}_{\mathrm{HA}}\right. \\
\left.+\mathrm{F}_{\mathrm{VA}}\right) / \mathrm{F}_{\mathrm{EC}} \\
\%\end{array}$ \\
\hline \multicolumn{12}{|c|}{ Ritten/Renon } \\
\hline Night & 315 & -32 & -178 & -5 & -215 & 666 & 13 & 96 & -5 & 104 & 799 \\
\hline Day & 660 & 241 & 68 & -5 & 303 & 126 & 184 & 113 & -6 & 291 & 158 \\
\hline All data & 978 & 152 & -12 & -5 & 135 & 89 & 129 & 107 & -5 & 230 & 179 \\
\hline \multicolumn{12}{|l|}{ Wetzstein } \\
\hline Night & 556 & -39 & -12 & -13 & -64 & 163 & 7 & 16 & 3 & 25 & 385 \\
\hline Day & 658 & 86 & 4 & 1 & 91 & 106 & 91 & 13 & -2 & 103 & 113 \\
\hline All data & 1242 & 27 & -4 & -5 & 18 & 68 & 51 & 14 & 1 & 66 & 129 \\
\hline \multicolumn{12}{|l|}{ Norunda } \\
\hline Night & 299 & -34 & 16 & 2 & -15 & 44 & 8 & 5 & 0 & 13 & 150 \\
\hline Day & 915 & 94 & 5 & 2 & 100 & 107 & 117 & -19 & -1 & 96 & 82 \\
\hline All data & 1255 & 60 & 8 & 2 & 69 & 116 & 88 & -14 & -1 & 73 & 83 \\
\hline
\end{tabular}

as at Ritten/Renon and Wetzstein (e.g. mean values for nighttime). In addition, we must be cautious given the evidence for possibly erroneous advective latent heat fluxes, especially for this site in relation to the applied discontinuous sampling strategy (see Section 3.2).
Vertical turbulent fluxes used in this study were determined by the EC method. This technique assesses turbulent exchange and therefore misses flux contributions during periods with insufficient turbulent conditions. Friction velocity $\left(u_{*}\right)$ can be used to detect such periods. Studies of $\mathrm{CO}_{2}$-exchange

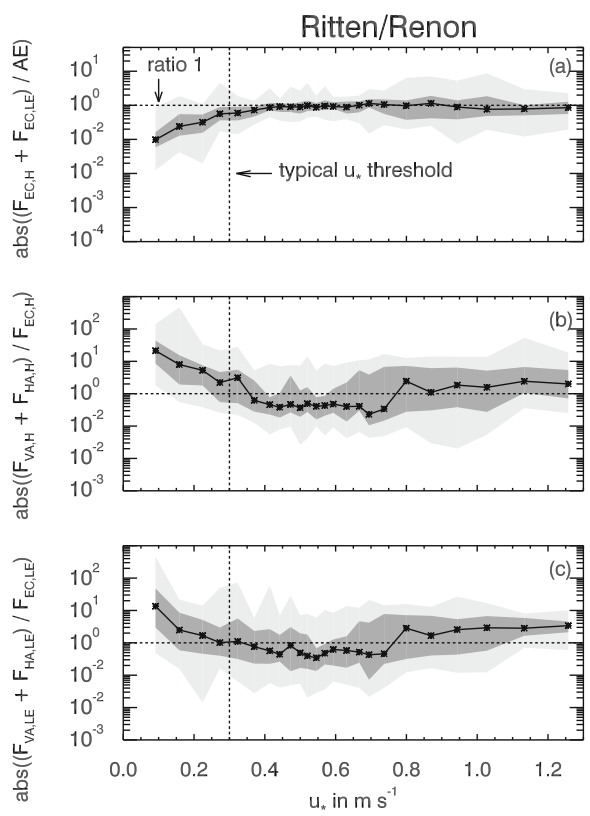

Fig. 9 Energy balance ratio without advective fluxes and relative magnitude of advective fluxes in relation to vertical turbulent flux. (a) Absolute values of energy balance ratios without advective fluxes in relation to friction velocity. $\mathrm{AE}$ denotes available energy, $\mathrm{AE}=R_{n}-G$ $-J$. (b) Absolute relative magnitude of sensible heat advection $\left(\mathrm{F}_{\mathrm{VA}, \mathrm{H}}+\right.$ $\left.\mathrm{F}_{\mathrm{HA}, \mathrm{H}}\right)$ in relation to sensible vertical turbulent flux $\left(\mathrm{F}_{\mathrm{EC}, \mathrm{H}}\right)$. (c) Absolute relative magnitude of latent heat advection $\left(\mathrm{F}_{\mathrm{VA}, \mathrm{LE}}+\mathrm{F}_{\mathrm{HA}, \mathrm{LE}}\right)$ in relation
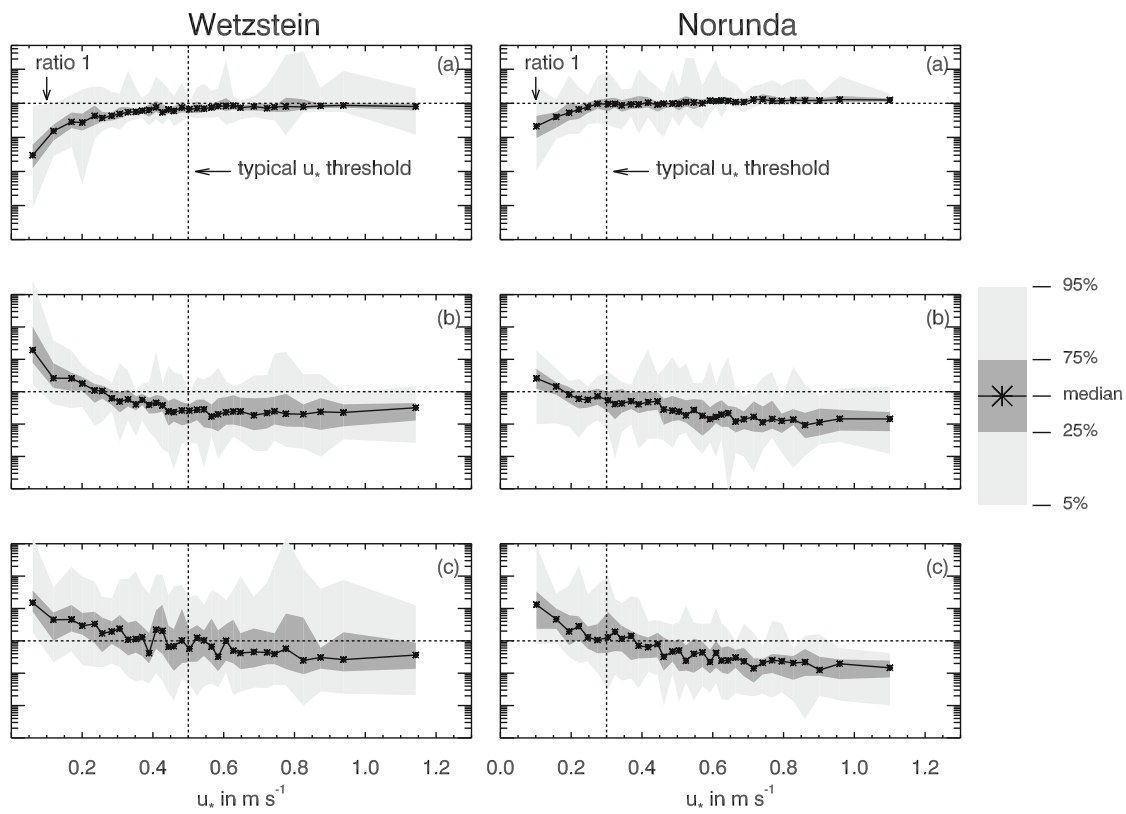

to latent vertical turbulent flux $\left(\mathrm{F}_{\mathrm{EC}, \mathrm{LE}}\right)$. Please note that the decreasing relevance of advective fluxes with increasing $u_{*}$ is mainly due to increases in $\mathrm{F}_{\mathrm{EC}, \mathrm{H}}\left(\mathrm{F}_{\mathrm{EC}, \mathrm{LE}}\right)$. Half-hourly data were binned. Each bin contains 40 values except bins corresponding to the largest values of $u_{*}$. This bin contains $61(58,59)$ values for Ritten/Renon (Wetzstein, Norunda). Please note that a logarithmic scale of ordinate and radiation corrected for surface inclination was used at Ritten/Renon 
Table 3 Energy balance ratio and results of simple linear regressions including and excluding advective fluxes

\begin{tabular}{|c|c|c|c|c|c|c|c|c|c|}
\hline & \multirow[b]{2}{*}{$n$} & \multicolumn{4}{|c|}{ Without advective fluxes } & \multicolumn{4}{|c|}{ including advective fluxes } \\
\hline & & $\begin{array}{l}\text { EBR } \\
-\end{array}$ & $\begin{array}{l}\mathrm{R}^{2} \\
-\end{array}$ & $\begin{array}{l}\text { slope } \\
-\end{array}$ & $\begin{array}{l}\text { offset } \\
\mathrm{W} \mathrm{m}^{-2}\end{array}$ & $\begin{array}{l}\text { EBR } \\
-\end{array}$ & $\begin{array}{l}\mathrm{R}^{2} \\
-\end{array}$ & $\begin{array}{l}\text { slope } \\
-\end{array}$ & $\begin{array}{l}\text { offset } \\
\mathrm{W} \mathrm{m}^{-2}\end{array}$ \\
\hline \multicolumn{10}{|c|}{ Ritten/Renon } \\
\hline Night & 315 & 0.32 & 0.07 & 0.19 & -7.9 & 1.85 & 0.44 & 2.37 & 31.3 \\
\hline Day & 660 & 1.10 & 0.68 & 0.92 & 68.2 & 1.54 & 0.62 & 1.22 & 120.9 \\
\hline All data & 978 & 1.16 & 0.80 & 0.95 & 50.7 & 1.51 & 0.77 & 1.39 & 30.3 \\
\hline \multicolumn{10}{|l|}{ Wetzstein } \\
\hline Night & 556 & 0.53 & 0.09 & 0.23 & -18.8 & 0.63 & 0.20 & 0.79 & 9.8 \\
\hline Day & 658 & 0.70 & 0.86 & 0.72 & -4.6 & 0.77 & 0.81 & 0.77 & 0.3 \\
\hline All data & 1242 & 0.75 & 0.91 & 0.69 & 6.2 & 0.81 & 0.86 & 0.76 & 5.5 \\
\hline \multicolumn{10}{|l|}{ Norunda } \\
\hline Night & 299 & 0.66 & 0.26 & 0.74 & 3.3 & 0.05 & 0.00 & -0.13 & -7.3 \\
\hline Day & 915 & 1.18 & 0.90 & 1.01 & 31.2 & 1.10 & 0.62 & 0.95 & 27.6 \\
\hline All data & 1255 & 1.22 & 0.93 & 1.03 & 23.8 & 1.19 & 0.67 & 0.94 & 30.2 \\
\hline
\end{tabular}

in particular use a so-called $u_{*}$ filter (Goulden et al. 1996; Falge et al. 2001; Aubinet et al. 2012b) where a critical value $\left(u_{*, \text { crit }}\right)$ is defined below which a considerable amount of flux is missed. Figure 9 shows how the contribution of advective fluxes in relation to the respective turbulent flux changes with friction velocity. The depicted critical values of friction velocity were taken from the literature (Ritten/Renon: $u_{*, \text { crit }}=$ $0.3 \mathrm{~m} \mathrm{~s}^{-1}$, Marcolla et al. 2005; Wetzstein: $u_{*, \text { crit }}=$ $0.5 \mathrm{~m} \mathrm{~s}^{-1}$; Anthoni et al. 2004, Zeri 2008; Norunda: $u_{* \text {,crit }}=$ $0.3 \mathrm{~m} \mathrm{~s}^{-1}$, Lagergren et al. 2008). As a starting point, we plotted binned data of absolute half-hourly energy balance ratios $\left(\mathrm{EBR}=\left(\mathrm{F}_{\mathrm{EC}, \mathrm{H}}+\mathrm{F}_{\mathrm{EC}, \mathrm{LE}}\right) /\left(R_{n}-G-J\right)\right)$ without considering advective fluxes against friction velocity (Fig. 9, subplots a). The energy balance ratio clearly decreased with decreasing values of $u_{*}$ for all sites and larger EBR were less frequent. If one assumes that most energy is missed due to advective transports during periods of low $u_{*}$, then the relative magnitude of advective fluxes should increase in relation to the vertical turbulent flux $\left(\mathrm{F}_{\mathrm{EC}}\right)$ with decreasing $u_{*}$. All the graphs depict advective fluxes which are much larger than the corresponding vertical turbulent flux for low values of $u_{*}$. In the case of larger values for $u_{*}$, advective fluxes tended to be smaller than the corresponding vertical turbulent flux. The crossing of the line indicating an EBR of 1 does not
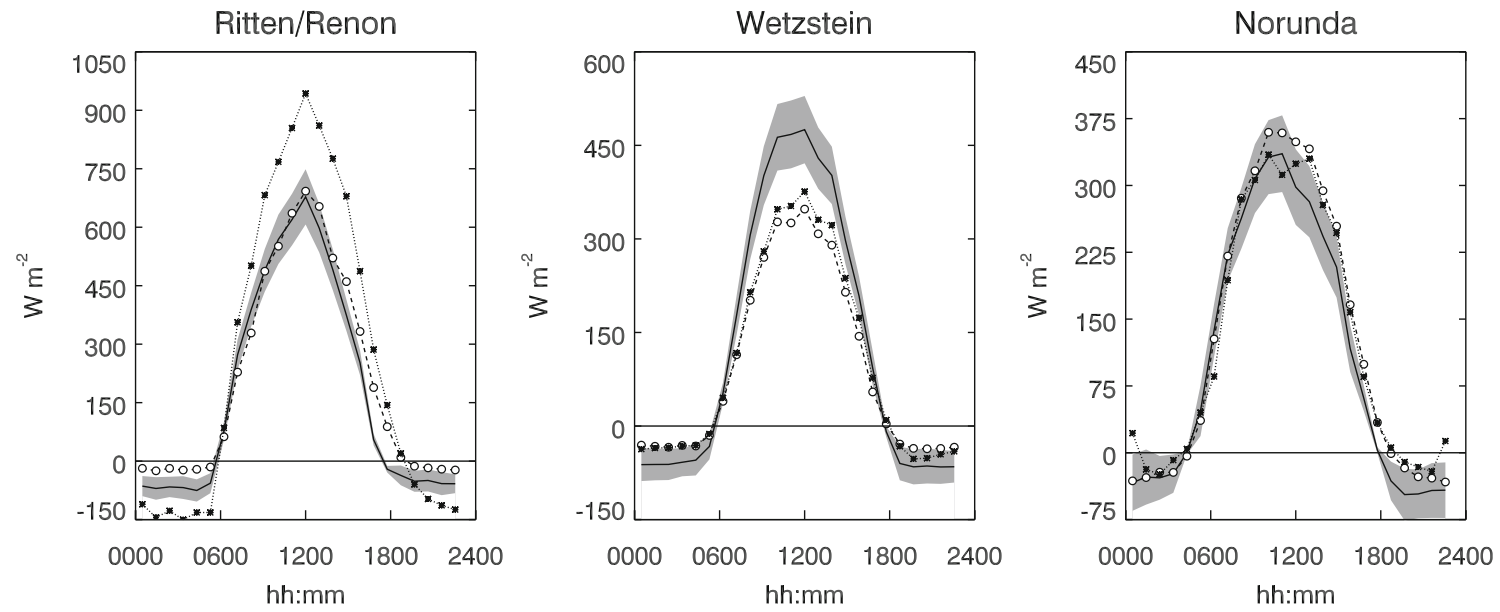

uncertainty range $\mathrm{AE}$

measured AE

0.-. - - oturbulent fluxes $\mathrm{H}+\mathrm{LE}$

* turbulent and advective fluxes $\mathrm{H}+\mathrm{LE}$

Fig. 10 Comparison of mean diurnal course of available energy (AE) and its estimated uncertainty range (according to Moderow et al. 2009) with and without consideration of advective fluxes, hourly means. Please note different scaling of $y$-axes 


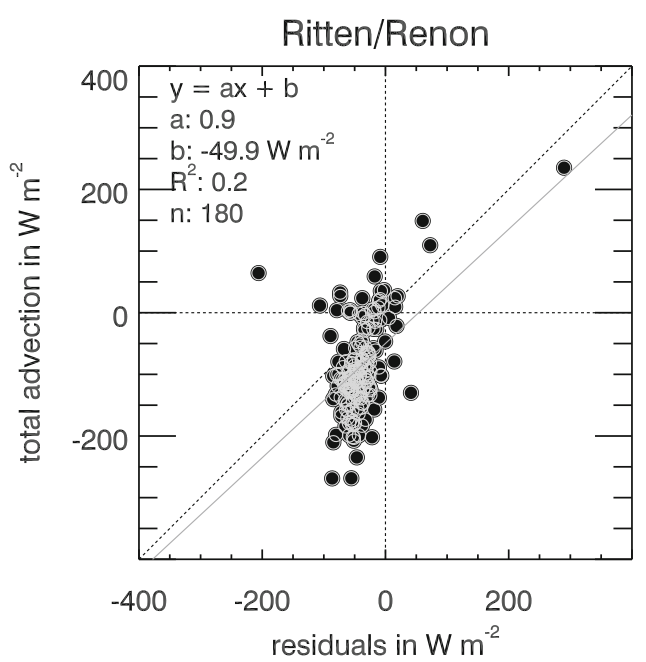

Fig. 11 Residuals of the energy balance not considering advective fluxes in relation to the total sum of advective fluxes based on half-hourly values. Results are shown for stable atmospheric conditions, i.e. $z / L>$ $0.05 \mathrm{~m} \mathrm{~m}^{-1}$. Each data point is represented by a black filled circle
Wetzstein

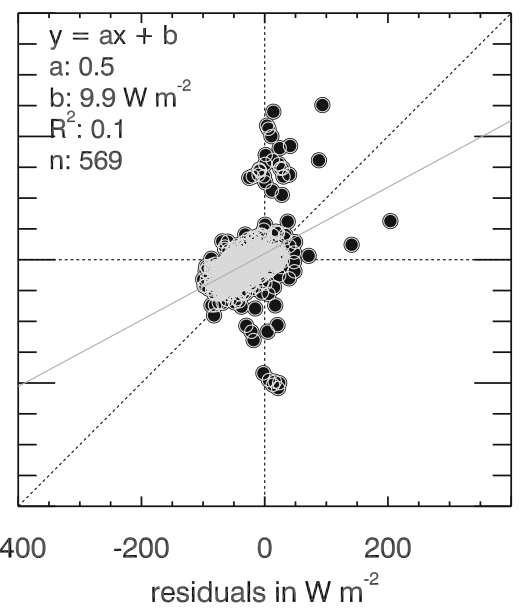

Norunda

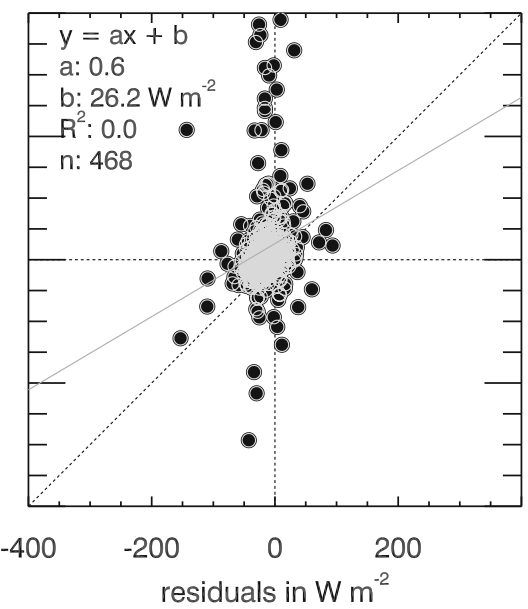

combined with an open light grey circle. Therefore, the greyer an area is the more data fall within this area. $n$ refers to the number of half-hourly values included in the respective regression. Grey solid line indicates the corresponding linear regression line and inclined dashed line the 1:1 line

necessarily coincide with reported friction velocity thresholds. In addition, advective fluxes also frequently remained nonnegligible for larger values of $u_{*}$. However, as single time series of advective fluxes did not consistently change with $u_{*}$, the decrease in magnitude relative to the vertical turbulent flux with increasing $u_{*}$ is mainly due to the well-developed dependency of $\mathrm{F}_{\mathrm{EC}, \mathrm{H}}$ and $\mathrm{F}_{\mathrm{EC}, \mathrm{LE}}$ on $u_{*}$. We interpret Fig. 9 in a cautious way: firstly, it supports the hypothesis that the importance of advective fluxes increases with decreasing friction velocity; secondly, that larger advective fluxes of energy could also exist for larger values of $u_{*}$; and thirdly that $u_{* \text {,crit }}$ determined for the vertical turbulent exchange of $\mathrm{CO}_{2}$ may not necessarily apply for energy fluxes to the same degree. Furthermore, the relative size of advective fluxes in relation to $\mathrm{F}_{\mathrm{EC}}$ (Fig. 9 subplots $\mathrm{b}$ and $\mathrm{c}$ ), together with depicted EBR (subplots a), indicate that the obtained advective fluxes are frequently too large to show perfect closure on a half-hourly basis. The subsequent analysis of the energy balance closure confirmed this.

Prior to inspecting the energy balance including advective fluxes, we analysed the influence of a possible underestimation of net radiation $\left(R_{n}\right)$ on the energy balance closure at Ritten/Renon. Moderow et al. (2009) reported an overclosure for this site, i.e. turbulent fluxes of sensible and latent heat redistributed more energy to the atmosphere than was available according to the measured available energy. Ritten/Renon is located on a comparatively steep slope which is approximately south-facing. However, radiation was measured perpendicular to the geopotential but not parallel to the surface. Therefore, radiation measurements possibly underestimated net radiation because an inclination of a surface alters its radiation gain. The energy balance using horizontally measured $\mathrm{R}_{\mathrm{n}}$ showed a linear relationship between $\left(R_{n}-G-\mathrm{J}\right)$ and $(\mathrm{H}+\mathrm{LE})$ of $y=a x+b: y=$ $1.02 x+49.85 \mathrm{~W} \mathrm{~m}^{-2}$, with a coefficient of determination of 0.80 and an energy balance ratio of 1.24 (no distinction between night and day). The use of surface parallel $R_{n}$ reduced the slope of the linear regression as well as the energy balance ratio but the offset of the linear regression was still large, indicating that a considerable amount of energy was still missed $(y=0.95 \mathrm{x}+$ $\left.50.74 \mathrm{~W} \mathrm{~m}^{-2} ; \mathrm{R}^{2}=0.80 ; \mathrm{EBR}=1.16\right)$. Although not all statistical measures improved, this still indicates an underestimation of the available energy at sloped sites if radiation measurements do not take place parallel to the surface, and this is in line with results of, for example, Leuning et al. (2012) and Wohlfahrt et al. (2016). Therefore, we used net radiation corrected for surface inclination for all further analyses.

In the next step, the fluxes of sensible and latent heat were related to the available energy to evaluate the energy balance closure (EBC). Table 3 gives results of linear regressions between $\left(R_{n}-G-J\right)$ and $(\mathrm{H}+\mathrm{LE})$ as well as energy balance ratios with and without consideration of advective fluxes. The energy balance changed differently for each site when advective fluxes were included. Overall, the EBC improved at Wetzstein. Wetzstein was situated on a ridge. Therefore, divergence (convergence) situations during night (day) connected with horizontal turbulent flux divergence were possible. Moderow et al. (2007) stated that horizontal flux divergence is approximately $10 \%$ of $\mathrm{F}_{\mathrm{EC}}$ in the case of sensible heat. Using this value for sensible heat as well as for latent heat this would further improve the energy balance closure for this site $(\mathrm{EBR}=0.89)$. 
In contrast, the overclosure at Ritten/Renon increased due to higher surface fluxes by advection, especially latent heat advection (Table 3 ). This resulted in very large energy balance ratios, as well as large slopes of linear regression, which we regard as physically questionable and are probably related to measurement problems. Most statistical measures for energy balance closure did not indicate a positive effect on the energy balance closure at Norunda. Figure 10 also shows an increase for latent heat fluxes when including advective fluxes at this site during nighttime. Very large horizontal advective fluxes often coincided with large values of relative humidity and low values of friction velocity here. Therefore, we assumed a considerable influence of measurement errors, possibly due to condensation. The coefficient of determination decreased in most cases for Ritten/Renon and Norunda when including advective fluxes, which indicated a less stringent relationship between available energy and surface fluxes.

We acknowledge that vertical turbulent fluxes can change if different post-processing schemes are applied, as shown by Mauder et al. (2007b). Based on the reported margins of Mauder et al. (2007b), Moderow et al. (2009) stated that this would not result in a closed energy balance for the investigated sites, the time intervals, and the data of vertical turbulent fluxes used here.

The inclusion of advective fluxes did not necessarily improve the energy balance closure (Table 3 and Fig. 10). We studied how the energy balance closure qualitatively changed for each half hour (closed, unclosed, or over-closed budgets). Energy balance was regarded as closed if the sum of latent and sensible heat flux fell within the uncertainty range of the available energy. The uncertainty range of available energy was defined according to Moderow et al. (2009). When the sum of latent and sensible heat flux fell outside of the range of uncertainty it was regarded as unclosed or overclosed (depending on its sign). The percentage of halfhourly values with a closed energy balance only increased for Wetzstein (from $45 \%$ to $52 \%$ ) and the number of half-hourly values with an over- or under-closure decreased at this site at the same time when including advective fluxes (from $65 \%$ to $59 \%$ ). At Ritten/Renon and Norunda, when advective fluxes were included the percentage of time intervals with a closed energy balance decreased (from $26 \%$ to $20 \%$ for Ritten/Renon and from $69 \%$ to $58 \%$ for Norunda). Consequently, the percentage of time intervals with an overclosure or underclosure correspondingly increased. For all sites, there were half hours which qualitatively changed in energy balance closure from underclosure to overclosure and vice versa.

In a further step, we analysed advective fluxes in relation to the energy balance residual (residual $=R_{n}-G^{-}$
$J-H-$ LE). If advective fluxes are the main cause of the energy balance closure gap then a relationship between the sum of the advective fluxes and the energy balance residuals should exist. For this analysis, residuals were calculated excluding advective fluxes. We then performed simple linear regressions for three classes of atmospheric stratification. Here, measurement height (z) divided by the Monin-Obukhov length (L) was used to evaluate atmospheric stability. The three classes of atmospheric stability were stable $\left(\mathrm{z} / \mathrm{L}>0.05 \mathrm{~m} \mathrm{~m}^{-1}\right)$, unstable $\left(\mathrm{z} / \mathrm{L}<-0.05 \mathrm{~m} \mathrm{~m}^{-1}\right)$, and neutral $\left(-0.05 \mathrm{~m} \mathrm{~m}^{-1} \geq \mathrm{z} / \mathrm{L} \leq\right.$ $\left.0.05 \mathrm{~m} \mathrm{~m}^{-1}\right)$. Coefficients of determination $\left(\mathrm{R}^{2}\right)$ indicated that the sum of advective fluxes and the energy balance residuals were uncorrelated for all investigated classes of atmospheric stability $\left(\mathrm{R}^{2} \leq 0.4\right.$, whereas five performed linear regressions yielded a $\mathrm{R}^{2}$ of 0.0 ). Previous studies reported similar results. Lee and $\mathrm{Hu}$ (2002) obtained a comparable result which stated that energy balance residuals showed almost no correlation with their estimates of vertical advection for midnight periods. Oncley et al. (2007) showed energy balance residuals and obtained advective energy fluxes within one graph. The corresponding graph of Oncley et al. (2007) indicated that energy balance residuals and advective fluxes did not necessarily linearly correlate.

Scatter plots for stable atmospheric conditions (Fig. 11) indicated that there was possibly a relationship for distinct ranges but a considerable number of the total sum of advective fluxes were too large, thus resulting in a poor correlation measure. We hypothesise that this is most probably due to systematic errors because the number of measurement points are probably too small to assess the ecosystem under consideration in a comprehensive way, although ADVEX was one of the advection experiments with a comparatively large number of measurement points. This would correspond with Leuning et al. (2008) and Aubinet et al. (2010) who stated that systematic errors constitute a major challenge in current advection studies and they cannot be simply reduced by long-term measurements. Especially at Norunda, measurements of moisture gradients are probably influenced by the applied discontinuous sampling scheme. Furthermore, the obtained residuals are also subject to errors in the determination of other energy balance components (e.g. $F_{E C, H}, F_{E C, L E}$ ). Therefore, even if we had more accurate and precise estimates of advection, this factor might not be able to explain residuals alone.

\section{Summary and conclusion}

The ADVEX dataset was used to estimate advective fluxes of sensible and latent heat for three coniferous sites across Europe differing in topography and stand characteristics. 
Derived half-hourly advective fluxes of sensible and latent heat were often quite large and characterised by large scatter for all sites. Well-marked diurnal variations were favoured by complex terrain. This was more striking for sensible heat than for latent heat advection.

The ratio $\left(\mathrm{F}_{\mathrm{HA}}+\mathrm{F}_{\mathrm{VA}}\right) / \mathrm{F}_{\mathrm{EC}}$ of the sum of horizontal and vertical advective fluxes $\left(\mathrm{F}_{\mathrm{HA}}+\mathrm{F}_{\mathrm{VA}}\right)$ to the vertical turbulent fluxes $\left(\mathrm{F}_{\mathrm{EC}}\right)$ increased with decreasing friction velocity $\left(u_{*}\right)$, mainly due to a decrease in the vertical turbulent fluxes with decreasing $u_{*}$. However, even for well-mixed conditions (typically daytime), substantial advective fluxes occurred.

The smallest advective fluxes were observed for Norunda (flat site with homogeneous canopy) but results clearly indicated that even quite homogeneous sites should be critically inspected regarding advection. The largest advective fluxes were detected for Ritten/Renon (sloped site in complex terrain and least homogeneous canopy structure). Diurnal variations of advective heat fluxes were governed by the local slope wind system at this site, which revealed that the flux budgets of sloped sites with local slope wind systems are consistently affected by advection. Furthermore, special synoptic situations can cause large advective fluxes at sloped sites, as shown by Feigenwinter et al. (2010b) in the case of $\mathrm{CO}_{2}$-advection. Use of radiation corrected for surface inclination improved the energy balance closure for Ritten/Renon and confirmed the results for other sloped sites (Leuning et al. 2012; SerranoOrtiz et al. 2016; Wohlfahrt et al. 2016).

Advection changed the budgets of sensible and latent heat for all sites. During nighttime, the budget of latent heat flux was relatively more affected by advective fluxes than the budget of the sensible heat flux for all sites; this is because vertical turbulent fluxes of latent heat were smaller than vertical turbulent fluxes of sensible heat during nighttime. When advective fluxes were included during nighttime, the transport of sensible heat into the control volume and the transport of latent heat out of the control volume increased for two of the inspected sites on average (Wetzstein, Ritten/Renon). This indicated an enhancement of nighttime evaporation by the additional energy input of sensible heat.

Advective fluxes changed the energy balance closure differently for each site. On average, the energy balance closure was only improved for one site (Wetzstein). A comparison of energy balance residuals (energy missed by the measurements without accounting for advection) to the total sum of advective fluxes indicated a large influence of systematic errors. This confirms a similar conclusion of Leuning et al. (2008).

Based on the comparison of the three sites, it can be further concluded that advective fluxes are highly site specific, which is in line with Yi et al. (2005), Aubinet et al. (2010), and Novick et al. (2014).

Acknowledgements We thank all technicians and scientists involved in the ADVEX experiments.
Funding Open Access funding enabled and organized by Projekt DEAL. This work was funded by the Deutsche Forschungsgemeinschaft (Contract GZ: BE 1721/10-1). Data were collected in the framework CarboEurope-Integrated Project of the European Commission (GOCECT2003-505572).

\section{Appendix}

Table 4 gives mean values of vertical advection $\left(\mathrm{F}_{\mathrm{VA}}\right)$ of sensible heat $\left(\mathrm{F}_{\mathrm{VA}, \mathrm{H}}\right)$ and latent heat $\left(\mathrm{F}_{\mathrm{VA}, \mathrm{LE}}\right)$ for each ADVEX tower and site. Ritten/Renon showed the largest differences in mean values. Wetzstein and Norunda showed differences of similar magnitude. Mean values of $\mathrm{F}_{\mathrm{VA}}$ did not differ significantly (Table 4) for some tower combinations. However, the obtained ranges of tower specific advection estimates were quite different (Fig. 12). There was no correlation between tower specific estimates for $\mathrm{F}_{\mathrm{VA}, \mathrm{LE}}$ on a half-hourly basis. In the case of $\mathrm{F}_{\mathrm{VA}, \mathrm{H}}$, there were weak correlations for all possible tower combinations (coefficient of determination $R^{2}: 0.2-0.4$ ) at Wetzstein, which was also true for one tower combination at Ritten/Renon

We hypothesise that the poor correlation between tower specific estimates of $\mathrm{F}_{\mathrm{VA}, \mathrm{H}}$ and $\mathrm{F}_{\mathrm{VA}, \mathrm{LE}}$ is due to estimates of the mean vertical velocities $(\bar{w})$. Tower specific estimates of $\bar{w}$ were uncorrelated for all possible tower combinations and all sites (maximum $R^{2}$ of 0.1 ). In contrast, vertical differences of potential temperature showed a good correlation $\left(R^{2}\right.$ range: $0.67-0.93)$ and a weak or reasonable agreement for vertical differences in mixing ratio $\left(R^{2}\right.$ range: $\left.0.37-0.87\right)$.

Table 4 Mean values of $\mathrm{F}_{\mathrm{VA}, \mathrm{H}}$ and $\mathrm{F}_{\mathrm{VA}, \mathrm{LE}}$ calculated if data of all four towers were available (rounded figures)

\begin{tabular}{|c|c|c|c|c|c|c|}
\hline & \multicolumn{2}{|c|}{ Ritten/Renon } & \multicolumn{2}{|c|}{ Wetzstein } & \multicolumn{2}{|l|}{ Norunda } \\
\hline & $\begin{array}{l}\mathrm{F}_{\mathrm{VA}, \mathrm{H}} \\
\mathrm{W} \mathrm{m}^{-2}\end{array}$ & $\begin{array}{l}\mathrm{F}_{\mathrm{VA}, \mathrm{LE}} \\
\mathrm{W} \mathrm{m}^{-2}\end{array}$ & $\begin{array}{l}\mathrm{F}_{\mathrm{VA}, \mathrm{H}}{ }^{\S} \\
\mathrm{W} \mathrm{m}\end{array}$ & $\begin{array}{l}\mathrm{F}_{\mathrm{VA}, \mathrm{LE}} \\
\mathrm{W} \mathrm{m}\end{array}$ & $\begin{array}{l}\mathrm{F}_{\mathrm{VA}, \mathrm{H}}{ }^{-2} \\
\mathrm{~W} \mathrm{~m}^{-2}\end{array}$ & $\begin{array}{l}\mathrm{F}_{\mathrm{VA}, \mathrm{LE}} \\
\mathrm{W} \mathrm{m}{ }^{-2}\end{array}$ \\
\hline Tower A & -3.0 & -12.0 & -3.0 & -0.5 & 0.0 & -1.0 \\
\hline Tower B & 8.0 & -5.0 & -5.0 & 0.5 & 3.0 & -0.5 \\
\hline Tower C & -4.0 & -4.0 & -5.0 & 0.5 & 2.0 & -0.0 \\
\hline Tower D & -24.0 & -3.0 & -7.0 & 2.0 & 2.0 & 0.5 \\
\hline
\end{tabular}

Mean values of the respective towers were tested using Wilcoxon rank test ( $p$ value 0.05 ) to see whether they significantly differ from each other

${ }^{\$}$ Ritten/Renon F $\mathrm{VA}_{\mathrm{V}, \mathrm{LE}}$ : Mean values of tower $\mathrm{B}$ and $\mathrm{C}$ did not differ significantly

${ }^{\S}$ Wetzstein $\mathrm{F}_{\mathrm{VA}, \mathrm{H}}$ : Mean values of tower $\mathrm{A}$ and $\mathrm{C}$, and tower B and C did not differ significantly

${ }^{\%}$ Wetzstein $\mathrm{F}_{\mathrm{VA}, \mathrm{LE}}$ : Mean values of tower $\mathrm{A}$ and $\mathrm{B}$, tower $\mathrm{A}$ and $\mathrm{C}$, tower $\mathrm{B}$ and $\mathrm{C}$, and tower $\mathrm{C}$ and $\mathrm{D}$ did not differ significantly

${ }^{\&}$ Norunda $\mathrm{F}_{\mathrm{VA}, \mathrm{H}}$ : Mean values of tower $\mathrm{A}$ and $\mathrm{B}$, tower $\mathrm{B}$ and $\mathrm{C}$, tower $\mathrm{B}$ and $\mathrm{D}$, and tower $\mathrm{C}$ and $\mathrm{D}$ did not differ significantly

${ }^{\#}$ Norunda $\mathrm{F}_{\mathrm{VA}, \mathrm{LE}}$ : Mean values of tower A and C, tower A and D, tower $\mathrm{B}$ and $\mathrm{C}$, tower $\mathrm{B}$ and $\mathrm{D}$, and tower $\mathrm{C}$ and $\mathrm{D}$ did not differ significantly 

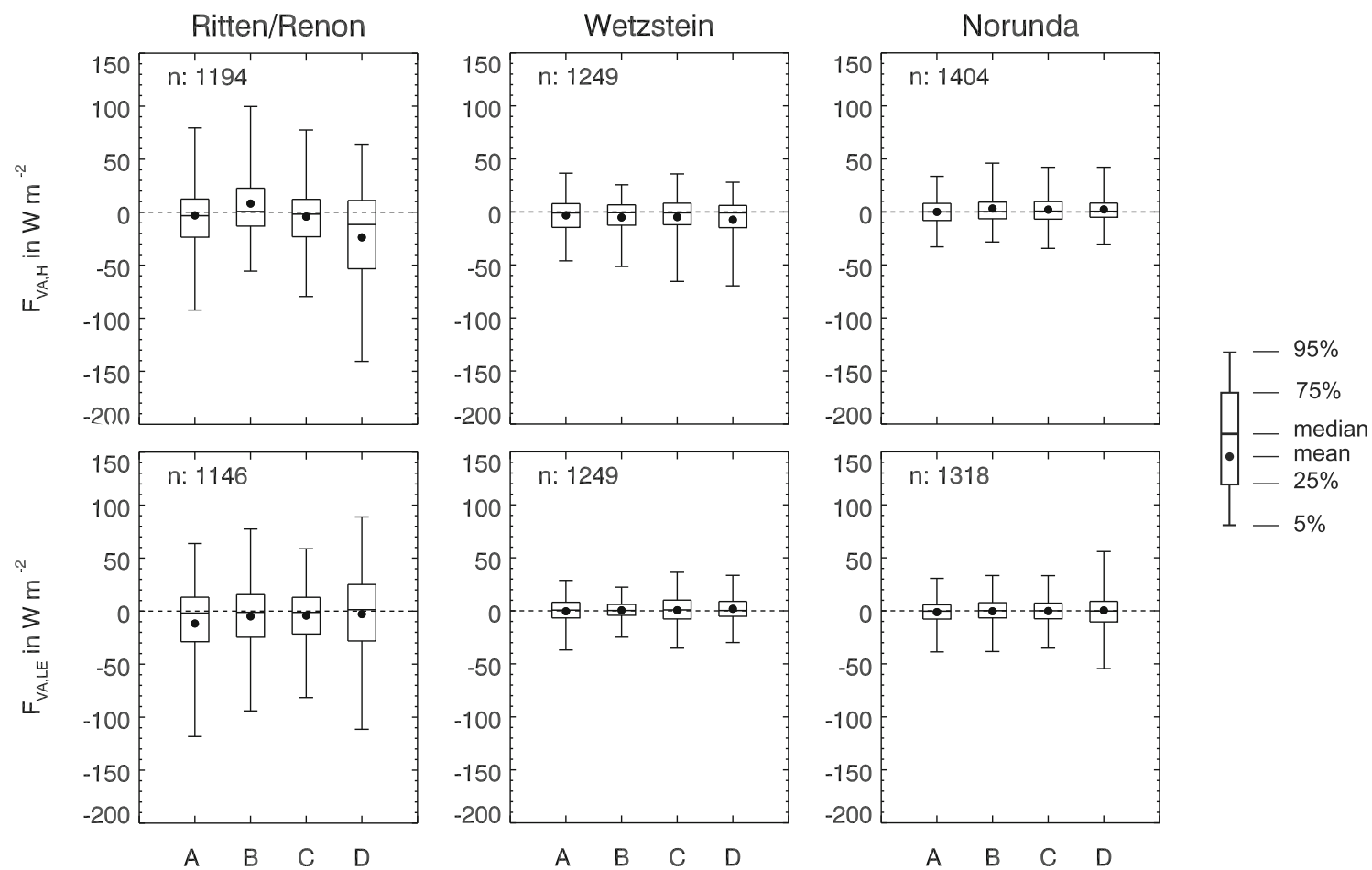

Fig. 12 Range of $\mathrm{F}_{\mathrm{VA}, \mathrm{H}}$ (upper panel) and $\mathrm{F}_{\mathrm{VA}, \mathrm{LE}}$ (lower panel) based on half-hourly values if data of all four towers were available

Open Access This article is licensed under a Creative Commons Attribution 4.0 International License, which permits use, sharing, adaptation, distribution and reproduction in any medium or format, as long as you give appropriate credit to the original author(s) and the source, provide a link to the Creative Commons licence, and indicate if changes were made. The images or other third party material in this article are included in the article's Creative Commons licence, unless indicated otherwise in a credit line to the material. If material is not included in the article's Creative Commons licence and your intended use is not permitted by statutory regulation or exceeds the permitted use, you will need to obtain permission directly from the copyright holder. To view a copy of this licence, visit $\mathrm{http}: / /$ creativecommons.org/licenses/by/4.0/.

\section{References}

Anthoni PM, Knohl A, Rebmann C, Freibauer A, Mund M, Ziegler W, Kolle O, Schulze ED (2004) Forest and agricultural land-usedependent $\mathrm{CO}_{2}$ exchange in Thuringia, Germany. Glob Chang Biol 10:2005-2019. https://doi.org/10.1111/j.1365-2486.2004. 00863.x

Aubinet M (2008) Eddy covariance $\mathrm{CO}_{2}$ flux measurements in nocturnal conditions: an analysis of the problem. Ecol Appl 18:1368-1378. https://doi.org/10.1890/06-1336.1

Aubinet M, Grelle A, Ibrom A, Rannik Ü, Moncrieff J, Foken T, Kowalski AS, Martin PH, Berbigier P, Bernhofer C, Clement R, Elbers J, Granier A, Grünwald T, Morgenstern K, Pilegaard K, Rebmann C, Snijders W, Valentini R, Vesala T (1999) Estimates of the annual net carbon and water exchange of forests: the EUROFLUX methodology. Adv Ecol Res 30:113-175. https://doi. org/10.1016/S0065-2504(08)60018-5

Aubinet M, Heinesch B, Yernaux M (2003) Horizontal and vertical $\mathrm{CO}_{2}$ advection in a sloping forest. Bound-Layer Meteorol 108:397-417. https://doi.org/10.1023/A:1024168428135

Aubinet M, Berbigier P, Bernhofer C, Cescatti A, Feigenwinter C, Granier A, Grünwald T, Havrankova K, Heinesch B, Longdoz B,
Marcolla B, Montagnani L, Sedlak P (2005) Comparing $\mathrm{CO}_{2}$ storage and advection conditions at night at different Carboeuroflux sites. Boun-Layer Meteorol 116:63-93. https://doi.org/10.1007/ s10546-004-7091-8

Aubinet M, Feigenwinter C, Heinesch B, Bernhofer C, Canepa E, Lindroth A, Montagnani L, Rebmann C, Sedlak P, Van Gorsel E (2010) Direct advection measurements do not help to solve the nighttime $\mathrm{CO}_{2}$ closure problem: evidence from three different forests. Agric For Meteorol 150:655-664. https://doi.org/10.1016/j. agrformet.2010.01.016

Aubinet M, Vesala T, Papale D (eds) (2012a) Eddy covariance-a practical guide to measurement and data analysis. Springer, Heidelberg, London, New York

Aubinet M, Feigenwinter C, Heinesch B, Laffineur Q, Papale D, Reichstein M, Rinne J, van Gorsel E (2012b) Nighttime flux correction. In: Aubinet M, Vesala T, Papale D (eds) Eddy covariance, Springer Atmospheric Sciences. Springer, Dordrech, pp 133-157. https://doi.org/10.1007/978-94-007-2351-1_5

Baldocchi DD (2003) Assessing the eddy covariance technique for evaluating carbon dioxide exchange rates of ecosystems: past, present and future. Glob Chang Biol 9:479-492. https://doi.org/10.1046/j. 1365-2486.2003.00629.x

Baldocchi DD (2014) Measuring fluxes of trace gases and energy between ecosystems and the atmosphere-the state and future of the eddy covariance method. Glob Chang Biol 20:3600-3609. https:// doi.org/10.1111/gcb.12649

Bernhofer C, Vogt R (1999) Energy balance closure gaps-a methodical problem of eddy covariance measurements. In: Proceedings of the international congress of biometeorology and international conference on urban climatology. Presented at the International Congress of Biometeorology and International Conference on Urban Climatology, Sydney, pp 199-203

Christen A, Van Gorsel E, Vogt R, Andretta M, Rotach MW (2001) Ultrasonic anemometer instrumentation at steep slopes-wind tunnel study-field intercomparison-measurements. Proceedings of MAP Meeting, Schliersee 
Collares-Pereira M, Rabl A (1979) The average distribution of solar radiation-correlations between diffuse and hemispherical and between daily and hourly insolation values. Sol Energy 22:155-164. https://doi.org/10.1016/0038-092X(79)90100-2

Etzold S, Buchmann N, Eugster W (2010) Contribution of advection to the carbon budget measured by eddy covariance at a steep mountain slope forest in Switzerland. Biogeosciences 7:2461-2475

Falge E, Baldocchi D, Olson R, Anthoni P, Aubinet M, Bernhofer C, Burba G, Ceulemans R, Clement R, Dolman H, Granier A, Gross P, Grünwald T, Hollinger D, Jensen NO, Katul G, Keronen P, Kowalski A, Lai CT, Law BE, Meyers T, Moncrieff J, Moors E, Munger JW, Pilegaard K, Rannik Ü, Rebmann C, Suyker A, Tenhunen J, Tu K, Verma S, Vesala T, Wilson K, Wofsy S (2001) Gap filling strategies for defensible annual sums of net ecosystem exchange. Agric For Meteorol 107:43-69. https://doi.org/10.1016/ S0168-1923(00)00225-2

Feigenwinter C, Bernhofer C, Vogt R (2004) The influence of advection on the short term $\mathrm{CO}_{2}$-budget in and above a forest canopy. BoundLayer Meteorol 113:201-224. https://doi.org/10.1023/B:BOUN. 0000039372.86053.ff

Feigenwinter C, Bernhofer C, Eichelmann U, Heinesch B, Hertel M, Janous D, Kolle O, Lagergren F, Lindroth A, Minerbi S, Moderow U, Molder M, Montagnani L, Queck R, Rebmann C, Vestin P, Yernaux M, Zeri M, Ziegler W, Aubinet M (2008) Comparison of horizontal and vertical advective $\mathrm{CO}_{2}$ fluxes at three forest sites. Agric For Meteorol 148:12-24. https://doi.org/10.1016/j. agrformet.2007.08.013

Feigenwinter C, Mölder M, Lindroth A, Aubinet M (2010a) Spatiotemporal evolution of $\mathrm{CO}_{2}$ concentration, temperature, and wind field during stable nights at the Norunda forest site. Agric For Meteorol 150:692-701. https://doi.org/10.1016/j.agrformet. 2009.08.005

Feigenwinter C, Montagnani L, Aubinet M (2010b) Plot-scale vertical and horizontal transport of $\mathrm{CO}_{2}$ modified by a persistent slope wind system in and above an alpine forest. Agric For Meteorol 150:665673. https://doi.org/10.1016/j.agrformet.2009.05.009

Finnigan JJ (1999) A comment on the paper by Lee (1998): “On micrometeorological observations of surface-air exchange over tall vegetation.". Agric For Meteorol 97:55-64. https://doi.org/10.1016/ S0168-1923(99)00049-0

Foken T (2008) The energy balance closure problem: an overview. Ecol Appl 18:1351-1367. https://doi.org/10.1890/06-0922.1

Foken T, Aubinet M, Finnigan JJ, Leclerc MY, Mauder M, Paw UKT (2011) Results of a panel discussion about the energy balance closure correction for trace gases. Bull Am Meteorol Soc 92:ES13ES18

Franssen HJH, Stöckli R, Lehner I, Rotenberg E, Seneviratne SI (2010) Energy balance closure of Eddy-covariance data: a multisite analysis for European FLUXNET stations. Agric For Meteorol 150:15531567. https://doi.org/10.1016/j.agrformet.2010.08.005

Gao Z, Liu H, Katul GG, Foken T (2017) Non-closure of the surface energy balance explained by phase difference between vertical velocity and scalars of large atmospheric eddies. Environ Res Lett 12: 034025. https://doi.org/10.1088/1748-9326/aa625b

Gassel A (1997) Beiträge zur Berechnung solarthermischer und energieeffizienter Energiesysteme Dissertation Technische Universität Dresden

Geissbühler P, Siegwolf R, Eugster W (2000) Eddy covariance measurements on mountain slopes: the advantage of surface-normal sensor orientation over a vertical set-up. Bound-Layer Meteorol 96:371392. https://doi.org/10.1023/A:1002660521017

Gerken T, Ruddell BL, Fuentes JD, Araújo A, Brunsell NA, Maia J, Manzi A, Mercer J, dos Santos RN, von Randow C, Stoy PC (2018) Investigating the mechanisms responsible for the lack of surface energy balance closure in a central Amazonian tropical rainforest. Agric For Meteorol 255:92-103. https://doi.org/10. 1016/j.agrformet.2017.03.023

Goldberg V (1999) Zur Regionalisierung des Klimas in den Hochlagen des Osterzgebirges unter Berücksichtigung des Einflusses von Wäldern, Tharandter Klimaprotokolle 2. Eigenverlag der TU Dresden, Dresden

Goulden ML, Munger JW, Fan SM, Daube BC, Wofsy SC (1996) Measurements of carbon sequestration by long-term eddy covariance: methods and a critical evaluation of accuracy. Glob Chang Biol 2:169-182. https://doi.org/10.1111/j.1365-2486.1996. tb00070.x

Heusinkveld BG, Jacobs AFG, Holtslag AAM, Berkowicz SM (2004) Surface energy balance closure in an arid region: role of soil heat flux. Agric Forest Meteorol 122:21-37. https://doi.org/10.1016/j. agrformet.2003.09.005

Higgins CW (2012) A-posteriori analysis of surface energy budget closure to determine missed energy pathways. Geophys Res Lett 39: L19403. https://doi.org/10.1029/2012GL052918

Higgins CW, Pardyjak E, Froidevaux M, Simeonov V, Parlange MB (2013) Measured and estimated water vapor advection in the atmospheric surface layer. J Hydrometeorol 14:1966-1972. https://doi. org/10.1175/JHM-D-12-0166.1

Holst T, Rost J, Mayer H (2005) Net radiation balance for two forested slopes on opposite sides of a valley. Int J Biometeorol 49:275-284. https://doi.org/10.1007/s00484-004-0251-1

Hong J, Joon K, Dongho L, Jong-Hwan L (2008) Estimation of the storage and advection effects on $\mathrm{H}_{2} \mathrm{O}$ and $\mathrm{CO}_{2}$ exchanges in a hilly KoFlux forest catchment. Water Resour Res 44. https://doi.org/10. 1029/2007WR006408

Kanemasu ET, Verma SB, Smith EA, Fritschen LJ, Wesely M, Field RT, Kustas WP, Weaver H, Stewart JB, Gurney R, Panin G, Moncrieff JB (1992) Surface flux measurements in FIFE: an overview. J Geophys Res 97:18547-18555. https://doi.org/10.1029/92JD00254

Klemm O, Chang SC, Hsia YJ (2006) Energy fluxes at a subtropical mountain cloud forest. For Ecol Manag 224:5-10. https://doi.org/ 10.1016/j.foreco.2005.12.003

Kochendorfer J, Paw UKT (2011) Field estimates of scalar advection across a canopy edge. Agric For Meteorol 151:585-594. https:// doi.org/10.1016/j.agrformet.2011.01.003

Lagergren F, Lindroth A, Dellwik E, Ibrom A, Lankreijer H, Launiainen S, Mölder M, Kolari P, Pilegaard K, Vesala T (2008) Biophysical controls on $\mathrm{CO}_{2}$ fluxes of three Northern forests based on long-term eddy covariance data. Tellus B 60:143-152. https://doi.org/10.1111/ j.1600-0889.2006.00324.x

Lee X (1998) On micrometeorological observations of surface-air exchange over tall vegetation. Agricu For Meteorol 91:39-49. https://doi.org/10.1016/S0168-1923(98)00071-9

Lee X, Hu X (2002) Forest-air fluxes of carbon, water and energy over non-flat terrain. Bound-Layer Meteorol 103:277-301. https://doi. org/10.1023/A:1014508928693

Leuning R, Zegelin SJ, Jones K, Keith H, Hughes D (2008) Measurement of horizontal and vertical advection of $\mathrm{CO}_{2}$ within a forest canopy. Agric For Meteorol 148:1777-1797. https://doi.org/10.1016/j. agrformet.2008.06.006

Leuning R, van Gorsel E, Massman WJ, Isaac PR (2012) Reflections on the surface energy imbalance problem. Agric For Meteorol 156:6574. https://doi.org/10.1016/j.agrformet.2011.12.002

Lindroth A, Mölder M, Lagergren F (2010) Heat storage in forest biomass improves energy balance closure. Biogeosciences 7:301-313. https://doi.org/10.5194/bg-7-301-2010

Lundin LC, Halldin S, Lindroth A, Cienciala E, Grelle A, Hjelm P, Kellner E, Lundberg A, Mölder M, Morén AS, Nord T, Seibert J, Stähli M (1999) Continuous long-term measurements of soil-plantatmosphere variables at a forest site. AgricFor Meteorol 98-99:5373. https://doi.org/10.1016/S0168-1923(99)00092-1 
Marcolla B, Cescatti A, Montagnani L, Manca G, Kerschbaumer G, Minerbi S (2005) Importance of advection in the atmospheric $\mathrm{CO}_{2}$ exchanges of an alpine forest. Agric For Meteorol 130:193-206. https://doi.org/10.1016/j.agrformet.2005.03.006

Marcolla B, Cobbe I, Minerbi S, Montagnani L, Cescatti A (2014) Methods and uncertainties in the experimental assessment of horizontal advection. Agric For Meteorol 198-199:62-71. https://doi. org/10.1016/j.agrformet.2014.08.002

Massman WJ, Lee X (2002) Eddy covariance flux corrections and uncertainties in long-term studies of carbon and energy exchanges. Agric For Meteorol 113:121-144. https://doi.org/10.1016/S01681923(02)00105-3

Matzinger N, Andretta M, Gorsel EV, Vogt R, Ohmura A, Rotach MW (2003) Surface radiation budget in an Alpine valley. Q J Roy Meteor Soc 129:877-895. https://doi.org/10.1256/qj.02.44

Mauder M, Jegede OO, Okogbue EC, Wimmer F, Foken T (2007a) Surface energy balance measurements at a tropical site in West Africa during the transition from dry to wet season. Theor Appl Climatol 89:171-183. https://doi.org/10.1007/s00704-006-0252-6

Mauder M, Oncley SP, Vogt R, Weidinger T, Ribeiro L, Bernhofer C, Foken T, Kohsiek W, Bruin HARD, Liu H (2007b) The energy balance experiment EBEX-2000. Part II: intercomparison of Eddycovariance sensors and post-field data processing methods. BoundLayer Meteorol 123:29-54. https://doi.org/10.1007/s10546-0069139-4

McGloin R, Šigut L, Havránková K, Dušek J, Pavelka M, Sedlák P (2018) Energy balance closure at a variety of ecosystems in Central Europe with contrasting topographies. Agric For Meteorol 248:418-431. https://doi.org/10.1016/j.agrformet.2017.10.003

Moderow U, Feigenwinter C, Bernhofer C (2007) Estimating the components of the sensible heat budget of a tall forest canopy in complex terrain. Bound-Layer Meteorol 123:99-120. https://doi.org/10. 1007/s10546-006-9136-7

Moderow U, Aubinet M, Feigenwinter C, Kolle O, Lindroth A, Molder M, Montagnani L, Rebmann C, Bernhofer C (2009) Available energy and energy balance closure at four coniferous forest sites across Europe. Theor Appl Climatol 98:397-412. https://doi.org/10.1007/ s00704-009-0175-0

Moderow U, Feigenwinter C, Bernhofer C (2011) Non-turbulent fluxes of carbon dioxide and sensible heat - a comparison of three forested sites. Agric For Meteorol 151:692-708. https://doi.org/10.1016/j. agrformet.2011.01.014

Nadeau DF, Pardyjak ER, Higgins CW, Huwald H, Parlange MB (2013) Flow during the evening transition over steep Alpine slopes. Q J Roy Meteor Soc 139:607-624. https://doi.org/10.1002/qj.1985

Novick K, Brantley S, Miniat CF, Walker J, Vose JM (2014) Inferring the contribution of advection to total ecosystem scalar fluxes over a tall forest in complex terrain. Agric For Meteorol 185:1-13. https://doi. org/10.1016/j.agrformet.2013.10.010

Odum EP (1983) Grundlagen der Ökologie, 2nd edn. Thieme, Stuttgart Oke TR (1987) Boundary layer climates, 2nd edn. Routledge, London

Oldroyd HJ, Pardyjak ER, Huwald H, Parlange MB (2016) Adapting tilt corrections and the governing flow equations for steep, fully threedimensional, mountainous terrain. Bound-Layer Meteorol 159:539565. https://doi.org/10.1007/s10546-015-0066-0

Oliveira PES, Acevedo OC, Moraes OLL, Zimermann HR, Teichrieb C (2013) Nocturnal intermittent coupling between the interior of a pine forest and the air above it. Bound-Layer Meteorol 146:45-46. https://doi.org/10.1007/s10546-012-9756-Z

Oncley SP, Foken T, Vogt R, Kohsiek W, DeBruin HAR, Bernhofer C, Christen A, van Gorsel E, Grantz D, Feigenwinter C, Lehner I, Liebethal C, Liu H, Mauder M, Pitacco A, Ribeiro L, Weidinger T (2007) The energy balance experiment EBEX-2000. Part I: overview and energy balance. Bound-Layer Meteorol 123:1-28. https:// doi.org/10.1007/s10546-007-9161-1
Paw UKT, Baldocchi DD, Meyers TP, Wilson KB (2000) Correction of Eddy-covariance measurements incorporating both advective effects and density fluxes. Bound-Layer Meteorol 97:487-511. https://doi.org/10.1023/A:1002786702909

Queck R, Bernhofer C (2010) Constructing wind profiles in forests from limited measurements of wind and vegetation structure. Agric For Meteorol 150:724-735. https://doi.org/10.1016/j.agrformet.2010. 01.012

Rebmann C, Zeri M, Lasslop G, Mund M, Kolle O, Schulze ED, Feigenwinter $\mathrm{C}$ (2010) Treatment and assessment of the $\mathrm{CO}_{2}$-exchange at a complex forest site in Thuringia, Germany. Agric For Meteorol 150:684-691. https://doi.org/10.1016/j.agrformet.2009. 11.001

Rebmann C, Kolle O, Heinesch B, Queck R, Ibrom A, Aubinet M (2012) Data acquisition and flux calculations. In: Aubinet M, Vesala T, Papale D (eds) Eddy covariance. A practical guide to measurement and data analysis. Springer, Dordrecht, pp 59-83

Ringgaard R, Herbst M, Friborg T (2014) Partitioning forest evapotranspiration: interception evaporation and the impact of canopy structure, local and regional advection. J Hydrol 517:677-690. https:// doi.org/10.1016/j.jhydrol.2014.06.007

Schulze ED, Ciais P, Luyssaert S, Schrumpf M, Janssens IA, Thiruchittampalam B, Theloke J, Saurat M, Bringezu S, Lelieveld J, Lohila A, Rebmann C, Jung M, Bastviken D, Abril G, Grassi G, Leip A, Freibauer A, Kutsch W, Don A, Nieschulze J, Börner A, Gash JH, Dolman AJ (2010) The European carbon balance. Part 4: integration of carbon and other trace-gas fluxes. Glob Chang Biol 16:1451-1469. https://doi.org/10.1111/j.1365-2486.2010.02215.x

Serrano-Ortiz P, Sánchez-Cañete EP, Olmo FJ, Metzger S, Pérez-Priego O, Carrara A, Alados-Arboledas L, Kowalski AS (2016) Surfaceparallel sensor orientation for assessing energy balance components on mountain slopes. Bound-Layer Meteorol 158:489-499. https:// doi.org/10.1007/s10546-015-0099-4

Siebicke L, Steinfeld G, Foken T (2011) $\mathrm{CO}_{2}$-gradient measurements using a parallel multi-analyzer setup. Atmos Meas Tech 4:409 423. https://doi.org/10.5194/amt-4-409-2011

Siebicke L, Hunner M, Foken T (2012) Aspects of $\mathrm{CO}_{2}$ advection measurements. Theor Appl Climatol 109:109-131. https://doi.org/10. 1007/s00704-011-0552-3

Staebler RM, Fitzjarrald DR (2004) Observing subcanopy $\mathrm{CO}_{2}$ advection. Agric For Meteorol 122:139-156. https://doi.org/10.1016/j. agrformet.2003.09.011

Stiperski I, Rotach MW (2016) On the measurement of turbulence over complex mountainous terrain. Bound-Layer Meteorol 159:97-121. https://doi.org/10.1007/s10546-015-0103-Z

Stoy PC, Mauder M, Foken T, Marcolla B, Boegh E, Ibrom A, Arain MA, Arneth A, Aurela M, Bernhofer C, Cescatti A, Dellwik E, Duce P, Gianelle D, van Gorsel E, Kiely G, Knohl A, Margolis H, McCaughey H, Merbold L, Montagnani L, Papale D, Reichstein M, Saunders M, Serrano-Ortiz P, Sottocornola M, Spano D, Vaccari F, Varlagin A (2013) A data-driven analysis of energy balance closure across FLUXNET research sites: the role of landscape scale heterogeneity. Agric For Meteorol 171-172:137-152. https:// doi.org/10.1016/j.agrformet.2012.11.004

Stull RB (1988) An introduction to boundary layer meteorology, atmospheric and oceanographic sciences library. Kluwer Adacemic Publisher, Dordrecht

Stull RB (2000) Meteorology for scientists and engineers, 2nd edn. Brooks/Cole Thomson Learning, Pacific Grove

Thomas CK (2011) Variability of sub-canopy flow, temperature, and horizontal advection in moderately complex terrain. Bound-Layer Meteorol 139:61-81. https://doi.org/10.1007/s10546-010-9578-9

Tsvang LR, Fedorov MM, Kader BA, Zubkovskii SL, Foken T, Richter SH, Zeleny Y (1991) Turbulent exchange over a surface with chessboard-type inhomogeneities. Bound-Layer Meteorol 55:141160. https://doi.org/10.1007/BF00119331 
Turnipseed AA, Blanken PD, Anderson DE, Monson RK (2002) Energy budget above a high-elevation subalpine forest in complex topography. Agric For Meteorol 110:177-201. https://doi.org/10.1016/ S0168-1923(01)00290-8

van Gorsel E, Harman IN, Finnigan JJ, Leuning R (2011) Decoupling of air flow above and in plant canopies and gravity waves affect micrometeorological estimates of net scalar exchange. Agric For Meteorol 151:927-933. https://doi.org/10.1016/j.agrformet.2011. 02.012

Varmaghani A, Eichinger WE, Prueger JH (2016) A diagnostic approach towards the causes of energy balance closure problem. Open J Mod Hydrol 06:101-114. https://doi.org/10.4236/ojmh.2016.62009

Whiteman CD, Allwine KJ, Fritschen LJ, Orgill MM, Simpson JR (1989) Deep valley radiation and surface energy budget microclimates. Part I: radiation. J Appl Meteorol 28:414-426. https://doi.org/10.1175/ 1520-0450(1989)028<0414:DVRASE >2.0.CO;2

Wilczak JM, Oncley SP, Stage SA (2001) Sonic anemometer tilt correction algorithms. Bound-Layer Meteorol 99:127-150. https://doi.org/ 10.1023/A:1018966204465

Wilson K, Goldstein A, Falge E, Aubinet M, Baldocchi D, Berbigier P, Bernhofer C, Ceulemans R, Dolman H, Field C, Grelle A, Ibrom A, Law BE, Kowalski A, Meyers T, Moncrieff J, Monson R, Oechel W, Tenhunen J, Valentini R, Verma S (2002) Energy balance closure at FLUXNET sites. Agric For Meteorol 113:223-243. https:// doi.org/10.1016/S0168-1923(02)00109-0

Wohlfahrt G, Hammerle A, Niedrist G, Scholz K, Tomelleri E, Zhao P (2016) On the energy balance closure and net radiation in complex terrain. Agric For Meteorol 226-227:37-49. https://doi.org/10. 1016/j.agrformet.2016.05.012

Wyngaard JC, Coté OR, Izumi Y (1971) Local free convection, similarity, and the budgets of shear stress and heat flux. J Atmos Sci 28: 1171-1182. https://doi.org/10.1175/1520-0469(1971)028<1171: LFCSAT>2.0.CO;2

Yi C, Davis KJ, Bakwin PS, Berger BW, Marr LC (2000) Influence of advection on measurements of the net ecosystem-atmosphere exchange of $\mathrm{CO}_{2}$ from a very tall tower. J Geophys Res 105:99919999. https://doi.org/10.1029/2000JD900080

Yi C, Monson RK, Zhai Z, Anderson DE, Lamb B, Allwine G, Turnipseed AA, Burns SP (2005) Modeling and measuring the nocturnal drainage flow in a high-elevation, subalpine forest with complex terrain. J Geophys Res 110. https://doi.org/10.1029/ 2005JD006282

Zeri $\mathrm{M}$ (2008) Investigation of high nighttime $\mathrm{CO}_{2}$-fluxes at the Wetzstein spruce forest site in Thuringia, Germany. Dissertation, Universität Bayreuth

Zeri M, Rebmann C, Feigenwinter C, Sedlak P (2010) Analysis of periods with strong and coherent $\mathrm{CO}_{2}$ advection over a forested hill. Agric For Meteorol 150:674-683. https://doi.org/10.1016/j. agrformet.2009.12.003

Publisher's note Springer Nature remains neutral with regard to jurisdictional claims in published maps and institutional affiliations. 